\title{
Grundtvig og censuren
}

\section{Af Flemming Lundgreen-Nielsen}

Grundtvigs 46 år lange engagement i trykkefrihedens teori og praksis flytter gradvis hans holdning. Han begyndte som 21-årig med at ville ajourføre trykkefrihedsbestemmelserne under særlig hensyntagen til dannede og videnskabeligt orienterede forfattere. I en længere midterperiode, der indbefatter hans egne 11 år under personlig censur, fremsatte han forskellige tekniske løsningsforslag til forbedring af forfatteres og taleres situation uden skade for samfundet. Han endte med som 67-årigt rigsdagsmedlem at gå ind for den videst mulige ytringsfrihed som det største gode.

Censur af skrifter begynder i Danmark fra og med lutherdommens sejr i reformationskampen. Problemet er aktualiseret med udbredelsen af den bogtrykkerkunst, der var kommet til landet i 1480'erne. Ifølge den lutherske Kirkeordinans, som blev skrevet på latin i 1537 og på dansk i 1539, udøvedes censuren i København af Universitetet og i provinserne af den lokale biskop.

Hovedprincippet kan udtrykkes i bibelstedet "Frygt Gud og ær kongen" (1 Pet 2,17). Man jagtede først navnlig angreb på troen, fx tvivl om Guds eksistens eller om sjælens udødelighed, og teologiske kætterier, der var imod protestantismens officielle lære. Efter enevældens indførelse i 1660 lagdes vægten i stigende grad på at forhindre kritik af kongen og hans hus, regering og øvrighed. Christian V's Danske Lov fra 1683 samlede de ofte gentagne påbud i 2-21-1-6, så det var repræsentanter for det fakultet ved Københavns Universitet, som en tekst hørte under, der skulle beslutte trykketilladelse ("Imprimatur"). Straffene for overtrædelse var i Danske Lov meget strenge: dødsstraf (tab af ære, liv og gods), landsforvisning på livstid eller på åremål, strafarbejde i jern på livstid, i mildere tilfælde tab af ære (offentlig agtelse), forbedringshusarbejde, fængsel på vand og brød eller bøder. Måske netop derfor afskrækkede de skribenterne, så de rejste sager blev få. I det 18 . århundredes praksis forekom disse straffe ikke før i 1790'erne.

Struensee afskaffede i 1770 enhver censur og indførte total trykkefrihed, der dog på grund af et væld af blandede, men mest usle, slibrige og i tilgift anonyme skriverier allerede i $1771 \mathrm{blev}$ modereret med indførelse af en regel om enten forfatter- eller bogtrykkernavn på hver tekst. Efter Struensees fald 17. januar 1772 og henrettelse 28. april samme år besluttedes det i 1773 at pålægge politimestrene at censurere massemedier som aviser, ugeblade og flyveblade og billeder (træsnit, kobberstik) og straffe overtrædelse med bøder, der ikke kunne 
appelleres. Den øvrige litteratur var fortsat ucensureret. Et reskript af 3. december 1790 flyttede pressesagerne fra politiet til domstolene, men politiet fik pligt til at indsende strafværdige tryk til justitsvæsenet. En væsentlig skærpelse kom med en ny forordning af 27 . september 1799, der forbød den forfatteranonymitet, som endnu var tilladt i 1771, og fordrede, at forfattere, trykkere og eventuelt også forlæggere med navns nævnelse hæftede for det skrevne. Politiet fik overdraget tilsyn med alle aviser og periodiske blade samt bøger under 24 ark (dvs. 384 tryksider). Hverken regeringsform eller den officielle religion måtte kritiseres. Desuden bestemtes, at enhver nok så lille overtrædelse pådømt efter 1799-forordningen medførte livsvarig censur for forfatteren, udøvet af den lokale politimester, og det gjaldt også bøger over 24 ark (som ellers kunne trykkes frit). På et ganske vist stærkt begrænset område var ældre tiders forhåndscensur hermed genindført.

Danmarks Riges Grundlov af 5. juni 1849 (revideret i 1866, 1915 og 1953) definerede, sammen med påfølgende presselove, det begreb om ytrings- og trykkefrihed under ansvar for domstolene, som gælder i dag. Grundloven fastslår, at "Censur og andre forebyggende forholdsregler kan ingensinde påny indføres" ( 777 i 1953-teksten). Under den tyske besættelse af Danmark 1940-45 blev denne paragraf tilsidesat, da der fra 29. august 1943 til 4. maj 1945 praktiseredes tysk censur på dansk presse og radio; også tidsskrifter og bøger kontrolleredes. For teaterstykker og film gjaldt desuden særlige censurinstanser, henholdsvis 1853-1954 og 1913-69.

Om mundtlige ytringer er der i tiden før 1849 ingen samlet lovgivning. Forespørgsler skulle i hvert enkelt tilfælde rettes til Det Kongelige Danske Cancelli, som besvarede dem ad hoc. Der skulle altid søges tilladelse til afholdelse af offentlige møder, hvor private borgere talte. Offentlige taler holdtes ellers af loyale embedsmænd, for eksempel ved flådens stabelafløbninger og på kongehusets festdage. I Højesteret, som lige fra sin oprettelse i 1661 havde mundtlig og offentlig sagsbehandling, talte advokaterne for eller imod i de verserende sager. Lærde med doktorgrad havde traditionelt ret til at tale på Universitetet, men det gjaldt i praksis kun inden for deres faglige emneområde, med de studerende som publikum. Myndighederne frygtede al ukontrollabel mundtlig tale. Henrich Steffens fik således $\mathrm{i}$ februar 1807 tilbudt en forskerstilling ved Københavns Universitet af kronprinsen, der imidlertid betingede sig, at han ikke måtte forelæse, fordi han gjorde ungdommen forrykt. ${ }^{1}$ Steffens var dog allerede i mismod over sensationsstemningen i København omkring hans filosofiske forelæsninger 1802-04 i sidstnævnte år emigreret til Tyskland og dets universitetsverden (Halle 1804-06 og 1808-11, 
Breslau 1811-32, Berlin 1832-45). Junigrundloven 1849 indførte forenings- og forsamlingsfrihed ( $§ 78-79$ i 1953-teksten).

\section{Grundtvigs første møder med censur}

Grundtvigs første publicerede tekst var et læserbrev i ugebladet Politivennen i januar 1804 om et ubesat skolelærerembede på Falster, og det fremkom kuriøst nok under det københavnske politikammers godkendelsesformular "Maae trykkes", fordi 1799-forordningen krævede dette af al journalistik. En begavet jævnaldrende studiekammerat, den bornholmske bondesøn P.N. Skougaard, udgav i sommeren 1804 som 21-årig bogen Beskrivelse af Bornholm, I, hvori han dels kritiserede samtidige lokale myndigheder på sin fødeø, dels dadlede den afdøde monark Frederik III for hans behandling af Corfitz Ulfeldt. Skougaards udsagn blev i 1805 dømt af Hof- og Stadsretten som usømmelige og skaffede ham en straf bestående af 14 dages fængsel på vand og brød, bøde for injurier, konfiskation af oplaget og automatisk livsvarig censur. Denne meget hårde dom, som Danske Cancelli endda forgæves søgte at få skærpet ved Højesteret, afsporede i forening med nogle måske problematiske ironiske og paranoide karaktertræk den ellers lovende unge forsker, hvad Grundtvig i 1827 brugte som eksempel på vilkårlig udøvelse af lovens bestemmelser (US V, 146). Uden at have fuldført sit studium og taget sine eksaminer flyttede han i 1807 til Aalborg, hvor han ernærede sig som skolelærer, kongelig translatør, skibsmægler, avisredaktør og portugisisk vicekonsul. Da han døde i 1838, kaldte en nekrolog indsendt til Aarhuus Stiftstidende ham "de censurdømtes Senior i Danmark". Han havde i årevis taget del i sin bys selskabsliv, men der gik rygter om en vis forsumpning, som i hvert fald var Grundtvig bekendt $(M M, 272)$. Skougaards udvortes liv i de sidste leveår minder indsenderen om Ewalds og Wessels menneskelige forfald (Nielsen 1966, 7-38, ${ }^{2}$ Steenstrup 1889, 160-162). Skønt Grundtvig i sin dagbog for 1804 ikke var ukritisk over for Skougaards bog (Albeck 1979, I, 169-176, jf. II, 136-139), gjorde retssagen indtryk på ham, dels fordi Skougaard var hans eneste nære ungdomsven, dels fordi han konkret havde været hans mentor i studiet af det gamle Nord. Den 31. december 1804 havde Grundtvig, antagelig i frygt for en landsforvisningsdom til Skougaard, rent ud i en nytårsopgørelse noteret, at denne syntes at skulle blive offer for "en umild Skjebne eller en ubillig Anvendelse af en barbarisk Trykkelov" (Albeck 1979, I, 178).

Tre år senere i sin Egeløkke-afhandling "Om Videnskabelighed og dens Fremme, især med Hensyn paa Fædrelandet", som blev trykt i K.L. Rahbeks tidsskrift $N y$ Minerva, 1807, forsvarer Grundtvig i 
urbane udtryk retten for en videnskabsmand til at skrive anonymt, når blot hans bogtrykker i påkommende tilfælde kan oplyse hans navn. Argumentet er, at anonymitetens ophævelse skader videnskaberne, fordi skribenter nødes til at formulere sig forsigtigere, end deres emner berettiger. Ydermere kan, mener han, begyndere have nytte af et skjold, der i deres prøvetid beskytter dem mod sårende personlig kritik. Før en professionel kritisk institution dannedes i Danmark, kunne censur ved velmenende embedsmænd faktisk vidtgående have en positiv faderlig funktion, således under Frederik V's regering 174666 (Koch 1889-90). I en fodnote spørger Grundtvig juristerne, om det skal anses for strafskyldigt at dadle en afdød dansk konge (US I, 180) - en klar henvisning til dommen over Skougaard. I øvrigt havde også to af underretsdommerne, H.G. Treschow og A.S. Ørsted, vurderet, at paragraffen om fornærmelse af kongen kun gjaldt levende, ikke afdøde monarker (Jørgensen 1944, 65). Men i og for sig regner Grundtvig i sin artikel fra 1807 ikke trykkefrihedsforordningen for nogen væsentlig hindring for videnskabelige fremskridt, "da det er en langt høiere Aand, hvis Nærværelse fremdriver, og hvis Fraværelse standser Presserne, saavidt disse staae i Videnskabeligheds Tjeneste" (US I, 181). Grundtvigs artikel indledes med et motto fra Horats' Ars poetica (v. 309): "Scribendi recte sapere est et principium et fons" (Viden er både grundlag for og kilde til at kunne skrive rigtigt). ${ }^{3}$

Under sin æstetisk-filosofiske periode på Langeland 1805-08 stiftede Grundtvig et læseselskab fortrinsvis beregnet på øens præster for selv at få lejlighed til at følge med i den moderne litteratur, han ikke havde råd til at købe. I februar 1807 beklagede en 61-årig præst sig over anskaffelsen af Odin Wolffs oversættelse af Boccaccios dristige noveller, I, 1805, på grund af dens mange smudsigheder. Myndighederne forbød da også fortsættelsen af værket på grund af dets anstødelige karakter. Som formand for selskabet imødegik Grundtvig klageren med historisk relativisme formuleret hvast og ungdommeligt stædigt: den italienske forfatter kunne ikke tage hensyn til "de ufødte Slægters mulige Begreber om det Anstændige i Fortællemaaden" (Lundgreen-Nielsen 1980, 196).

Det er derfor logisk, at Grundtvig i maj 1809 i en artikel om Jens Baggesen i Kjøbenhavnske loerde Efterretninger morede sig over dennes versfortælling "Kallundborgs Krønike, eller Censurens Oprindelse". Den var anonymt blevet optaget i tidsskriftet Minerva, 1786, og optrykt i Baggesens samlinger af Ungdomsarbeider, I, 1791, og Eventyrer og Comiske Fortcellinger, 1807. Grundtvig kategoriserer den som Baggesens eneste ægte komiske forsøg, men nævner dog slet ikke den indlagte kvikke anekdote om den to gange hængte tyv - en gedigen spøg, instrumenteret i Wesselsk stil. ${ }^{4}$ For ham er hovedsagen 
den holbergske rammehistorie om censurens oprindelse på kong Dans tid. Den indførtes ifølge Baggesen af en hestedum borgmester i Kallundborg ved navn Peer Asen, som følte sig truffet af en karikatur i en tekst skrevet et århundrede, før han blev født. Grundtvig hilser på skrømt borgmesterens indfald velkomment, "thi den Slags Satire er netop den allerfarligste, fordi den skiuler sig under Uskyldigheds Maske, og gaaer umistænkt sin lumske Gang fra Slægt til Slægt" (Grundtvig 1809, 284). Derimod synes Grundtvig ikke om Baggesens alvorligt mente klageråb over censurens skadelige følger: "Man tabte Vid med Modet, og blev dum. / Og endelig man skrev aldeles ikke", så "Mæsket Dumhed leer / Paa den Ruin, hvor Kundskab hungrig græder!" (Arlaud 1889, 181-182). Denne slutning "forstyrrer det komiske Indtryk" for Grundtvig (ibid., 285). Han bemærker en halv side før, at censur er ægte komisk, når man blot ikke "lader sig forvilde ved Synet af alt det Sørgelige, den har afstedkommet; thi det har den tilfælles med alle Troldpuslinge.” Er han måske ikke enig i Baggesens vurdering af de fatale følger af censur?

I Verdenskrøniken fra 1812 roser Grundtvig stadig "Kallundborgs Krønike" for en latter, der er "ægte, og i visse Maader priselig" (US II, 375) - men altså ikke i alle måder. I et utrykt manuskript fra efteråret 1818 forklarer Grundtvig sig nærmere: "er det maaskee mueligt, (...) uden Overdrivelse at fremstille Presse-Tvang fra en latterligere Side, end ved at lade den opstaae af Harme over Historiens Satiriskhed; hvor lyslevende fremspringer ikke her, midt under Latteren, den simple men saa tit glemte Sandhed, at man ved at binde Øieblikkets Mund, aabner Fortidens og væbner Efter-Tidens mod sig!" (Fasc. 180.131 r-31 v, jf. Lundgreen-Nielsen 1966, 150). Opgøret med censur hos Baggesen, "en af vore bedste Danske Digtere og et af hele Verdens vittigste Hoveder", vender han tilbage til 27 år senere (Grundtvig 1845, 44), og han husker under ændrede omstændigheder i 1849 endnu beskrivelsen af Kallundborgs paradisiske ånds- og kulturliv under trykkefriheden (Danskeren II, 103). Grundtvig hægter en "Følge-Seddel" på med referat og citater af Baggesen, fordi denne hans "Politi-Censurens Slægtebog" påviser, at censur ikke fødes af irritation over "Trykke-Frihedens virkelige Brodd", men af en indskrænket øvrighedspersons forstyrrede middagssøvn og groft misforståede læsninger af en tekst (108-112). Sigtet kan være 1799forordningens $\S 13$, der kræver domfældelse af allegoriske eller ironiske tekster, hvis sande mening og onde hensigt er umiskendelig, og de vilkårligheder, den i 50 år havde affødt fra censorernes side.

Grundtvig offentliggjorde i maj 1810 sin Dimisprædiken - en teologisk-praktisk eksamensopgave bedømt til egregie, dvs. udmærkelse. Den indeholdt retorisk velformede angreb på præstestanden som 
lidet troende levebrødsforkyndere, og det klagede seks københavnske præster til Cancelliet over. Det teologiske fakultet frarådede en retlig proces, så episoden endte ved kongelig indgriben med en temmelig ujuridisk irettesættelse fra rektor til Grundtvig for at have villet gøre opsigt ved at udsende teksten for et publikum, den ikke var skrevet til. Bogens æstetiske kvaliteter sikrede den øjeblikkelig tre oplag, og en tysk oversættelse fulgte i 1811. Grundtvig optrykte teksten som et historisk dokument om sig selv i sine Bibelske Prcedikener, 1816. Men nogen trykkefrihedssag blev det ikke til - "Tugtelsen blev blot literair", husker han i 1827 (US V, 113).

\section{Grundtvigs brug af trykkefrihedsforordningen}

På et landemode for Sjællands stift i oktober 1811 i Roskilde afviste Grundtvig et anonymt forslag om anskaffelse af et bibliotek af kristendomskritiske skrifter, så præsterne kunne møde deres modstandere. Det sker med det gode, men ubibelske argument, at Noah heller ikke medtog vandrotter i sin ark. Grundtvig vil hverken vide af den lumpne Voltaire eller den uterlige $* * *$ (dvs. T.C. Bruun). I sin Verdenskrønike, 1812, behandler Grundtvig Struensees totale pressefrihed som udbrud af "Liderlighed" og "alskens Uhumskhed" af "skidne Kildespring" (US II, 368). 1799-trykkeforordningen, som "bød Skribenterne nævne sig, og satte Straf for frække Angreb paa Tro og gode Sæder, Regering og enkelt Mand" (US II, 380), nævner Grundtvig med sympati, skønt den skabte tavshed på den åndelige børs: "Man sukkede over dens Palladium, uden at ville indse, at det Ilion, Loven kunde og vilde omstyrte, maatte være bygt af Ugudelighed og Uteerlighed, Æreskænderi og Oprørstale” (US II, 382). "Palladium" betyder "værnebillede, beskyttende funktion" og er i øvrigt et citat fra Baggesens Kallundborg-digt (Arlaud 1889, 180, jf. brevcitat fra 1794 i Baggesen 1844, 119), og Ilion er Troja, hvis Pallas Athene-billede, der sikrede byen mod erobring, blev stjålet af Diomedes og Odysseus. I stedet for at henvise til det historiske Trojas heroisme kritiserer Grundtvigs udtryk det degenererede Troja, som hans egen samtid kan siges at udgøre.

På landemodet i Roskilde i juli 1812 oplæste Grundtvig en tale, "Om Oplysning i Almindelighed og Almueoplysning i Særdeleshed" (Grundtvig 1812a), hvor han i et motto med et Paulus-citat (2 Kor 11,14-15) betegner de af samtidens præster, der harmoniserer kristendom og oplysning, som forklædte apostle af Satan. Det foranledigede en lille træfning (Lundgreen-Nielsen 1980, 526-527). En åbenbart fornærmet deltager skrev anonymt i avisen Dagen en måned senere, at foredragene på landemoderne burde forhåndscensureres af 
"duelige Mænd". Grundtvig replicerede i avisen Nyeste Skilderie af Kjøbenhavn midt i september - i en af censor let ændret form! $!^{5}$ - at "Noget mere Taabeligt, Noget mere Rasende eller og Ondskabsfuldt lader sig ikke tænke". Han kan ikke acceptere anden censur af "det levende Ord" end den, bispen udøver som leder af landemodeforsamlingens åbne debat. Artiklen nævner samtidig, at Grundtvig hellere end gerne så, at en samlet udgave af den liderlige forfatter T.C. Bruuns satiriske versdigtning blev standset af myndighederne på grund af blasfemi og usædelighed. Et udkast til en adresse til Frederik VI om sagen er bevaret i manuskript, men har nok ikke kunnet tiltrække underskrivere på landemodet. Bruuns skrifter udkom uanfægtet i syv bind 1812-31.

\section{Mangelen på en kritisk institution}

En heftig litterær strid mellem 12 unge Oehlenschläger-beundrere (fra Regensen) og digterkongens pedantisk-skarpe kritiker, Jens Baggesen, rasede i København i andet halvår af 1818. Den kaldes tylvtefejden, fordi Baggesen hånede de unge for at være så anonyme og ens som en tylvt, et fagudtryk for et dusin brædder, der kun som mængde har værdi. Grundtvig prøvede at stille trætten ved at tillægge sig en saglig og upartisk overdommerfunktion (jf. Lundgreen-Nielsen 1980, 801831). Han foreslog således i artiklen "Om Publicum og Publicums Domstol" (US III, 556-572), at der dannedes en litterær retsinstans besat med ældre modne litterater. Han fremhæver, at recensenter ikke skal være med, fordi de ikke er rigtige forfattere, men blot anmelder som "Peer og Poul synes, han vilde gjort, derom han kunde have gjort Andet end fortælle, hvad han synes om det, andre har gjort", Grundtvig citerer Baggesen for at kalde den slags et "Djovelskab", selv giver han det navn af en "Uting" (564). I et par utrykte udkast overvejer Grundtvig organiseringen af en sådan domstol. Der skal være en "Vagt i Literaturen" bemandet med æstetiske forfattere dels i 30'erne, dels i 60'erne, som kan indbringe litterært ustyr ("DrengeLarm og Spectacler") for et "Oldings-Raad" (dvs. senat) af offentligt anerkendte forfattere, udtaget af midaldrende kolleger. Rådsmedlemmerne har pligt til at udtale sig ærligt, når de drøfter en sag, og deres argumenter og kendelse nedskrives og opbevares, så publikum kan rekvirere dem til gennemsyn og oplysning. En sådan litterær institution blev dog ikke til noget, skønt Grundtvigs pointe fornuftigt nok var, at der burde skelnes mellem den officielle skole opretholdt af staten og for statens skyld og så den friskole, "den literaire Republik" kunne siges at udgøre. Statens skolevæsen reguleres ved økonomi og jura, mens friskolen, skønt underlagt statslige trykkelove, for 
Grundtvig langt mere præges af åndelig smidighed, af en vekselvirkning mellem forfattere og læsere og navnlig af et sigte ud over sin egen tid (Lundgreen-Nielsen 1980, 807-808).

I Baggesens "Fortale. Til mit Fædrenelands studerende Ynglinger", skrevet i august 1818 og optaget i parodien Breve til Adam Øhlenslager (I Anledning af En Reise af.en Dito), 2. oplag udgivet 23. september, efterlyses ligeledes en upartisk og ubestikkelig kritik, fordi "Skrivefrihed i en Literatur uden Kritik nødvendigen maa udarte til Trykkefrakhed" og vil resultere i en forvandling af litteraturen til "Maculatur i enhver Ordets egentlige og uegentlige Betydning", under mottoet Jo galere, jo bedre (omkvædet fra rundsangen i den 1774 tilsatte Epilog til Wessels Kierlighed uden Strømper, 1772) (Baggesen 1856, Tillag, 184). 1. oplag af bogen bar et gemytligt motto fra Baggesens egen "Kallundborgs Krønike", hvor den mislykket henrettede tyv opfordres til at bande på, at han er i live (Arlaud 1889, 171), i 2. oplag erstattes det af et løsrevet Horats-citat (Ep. II.ii, v. 214215): "Ludisti satis, edisti satis, atque bibisti: / Tempus abire est" (Du har spøgt tilstrækkeligt, du har ædt og drukket tilstrækkeligt, nu er det på tide, at du går din vej), i den unævnte kontekst skal det ske, for at den kåde ungdom ikke skal håne den tiltalte digters gammelmandsrus. Begge citater sigter til den modne Oehlenschläger, der i Baggesens øjne er blevet åndløs. Da nydte måltider spiller en vis rolle i Oehlenschlägers troskyldige bog En Reise fortalt i Breve til mit Hiem, I-II, 1817-18, kaldte Baggesen hånligt udgivelsen for "Ædedigtet". ?

\section{Grundtvig under censur}

Grundtvigs appel i tylvtefejden om en skelnen mellem borgerlig og litterær vurdering var forgæves. I kraft af sin præsteed, som han nu forstod den, skrev han i bogen Kirkens Gienmole, 1825, en skarp og barsk formuleret gendrivelse af angivelige kætterier i den teologiske professor H.N. Clausens værk om katolicismens og protestantismens kirkeforfatning, lære og ritus. To år efter kaldte Grundtvig det i en kasseret passage $i$ et manuskript ligeud for "en ung theologisk Professors volumineuse Prøve-Klud af opfarvet Tøi fra det attende Aaarhundrede" (US V, 118). Clausen gjorde den teologiskvidenskabelige debat juridisk ved at anklage Grundtvig for injurier (Bøje 1984, 34-65). Af mange årsager, som siden været diskuteret i forskningen, nedlagde Grundtvig 8. maj 1826 sit embede ved Vor Frelsers Kirke. ${ }^{8}$ Den 30. oktober 1826 faldt der dom, hvorefter Grundtvig kendtes skyldig i "fornærmelige Udladelser", der skulle mortificeres - uden at domsteksten i øvrigt opregner dem (Dam 1999, $18,24)$. Grundtvig blev ikke dømt for at have krænket Clausens ære, 
og egentlig var både dom og straf meget mild. Men ifølge 1799forordningens $\S 20$ medførte en trykkefrihedsdom automatisk livsvarig censur udøvet af den stedlige politimester, og det måtte umiddelbart for en forfatter med Grundtvigs produktivitet forekomme som en åndelig dødsdom.

Ikke desto mindre har Grundtvig - formentlig umiddelbart efter dommen - villet takke Frederik VI for 20 års beskyttet tilværelse som kongeskjald. Det sker i et digt på 13 6-linjede strofer med titlen "SagaTak til Dane-Kongen" (PS V, 476-479, ${ }^{9}$ Fasc. 388.108-109; 402.c.9). Kongens unåde må skyldes andre, skriver Grundtvig, så "At Sagastaven kom under Slaa, / Hvor Fredrik hersked', kun nævnes maa / En uforklarlig Gaade". Strofe 10 antyder en nødvendig emigration over det vilde hav - til England eller Amerika? - for at søge ly til historieskrivning og digtning, men betoner, at skjalden aldrig var til salg "For Verden og dens Vinding". Tanken om at udvandre fra Danmark erindrer Grundtvig siden i 1838 (MM, 487). Digtet kendes fra to renskrifter $\mathrm{i}$ fremmed hånd, som nederst har sat et "Allerunderdanigst", så de har vel været tænkt som bønskrivelser til kongen. Et noget afvigende egenhændigt udkast er i øvrigt bevaret under titlen "Taksigelsen" (PS V, 479-481, Fasc. 388.112). Allerede før embedsnedlæggelsen havde Grundtvig i et digt, hans søn Svend gav titlen "Mørke Udsigter", villet takke kongen for 16 års beskyttelse (PS V, 382-383, Fasc. 388.101). Alle disse tekster offentliggjordes først i 1883.

Da Grundtvig i marts 1827 udgav Skribenten Nik. Fred. Sev. Grundtvigs Literaire Testamente, er det imidlertid så langt fra at være en dødsattest, at han allerede i fortalen erklærer aldrig at have følt sig "saa ordenlig prosaisk lyslevende som nu" (US V, 156), og selve pjecen er skrevet i en næsten overgiven stemning, på én gang humoristisk og optimistisk. Det er en passende optakt til den fornyelse, som Grundtvig ikke vidste ventede ham under og efter de tre Englandsrejser i somrene 1829, 1830 og 1831.

Den 8. april 1827 søgte Grundtvig i et omhyggeligt retorisk opsat bønskrift Frederik VI om fritagelse fra censur ( $B G$ II, 135-137), men det afsloges. Grundtvig ytrede sig efterfølgende bittert om de embedsmænd, der håndterede sagen, mens han hyldede kongen lige så oprigtigt og hjerteligt som før. Faktisk med rette, for Frederik VI havde stadig megen godhed for sin iltre præst, men skulle samtidig tænke på at bevare freden i statskirken. Grundtvigs pæne kongelige aflønning fra og med 1818 for national historieskrivning - fra begyndelsen sat til halvdelen af professor Oehlenschlägers årsgage blev således ikke rørt, men fortsatte til 1842 (Rasch, 34). 
Theologisk Maanedsskrift bragte i 1827 en længere afhandling af Grundtvig med titlen "Om Religions-Frihed". De to første dele (på 66 sider) udkom som planlagt. Tredje og sidste del (73 sider) var faktisk blevet trykt med censor P. Eberlins Imprimatur af 6. marts, men da Grundtvig ræsonnerede videre over retssagen med Clausen og appellerede direkte til kongelig indgriben, beslaglagdes oplaget af Cancelliet og blev først i 1866 løsladt fra politikammeret (SJ I, 215, SJ IV, 39).

Teksten indeholder en del overvejelser over ytringsfrihed. Indledende tvivler Grundtvig på, at "Politi-Censur er anvendelig ved private Søgs-Maal", og beslutter sig til at anse "dens Anvendelse paa mig for en blot Formalitet" (US V, 97). I 1770 "ved Censurens uforberedte, ubesindige Ophævelse" blev mirakuløst "selv den ubestemte, regelløse, revolutionære, i saamange Henseender for hver Alvors-Mand modbydelige Trykke-Frihed" et frelsende middel i forsynets, kronprinsens og hans statsråds hænder (105). Grundtvig bekender sig gerne til "det attende Aarhundredes Læse-Verden", hvorfra han medtog just "de liberale Ideer om aandelig Krig og borgerlig Fred", der nu er kommet ham dyrt at stå (106-107). I 1824 måtte Grundtvig se i øjnene, at på en tid, "da Trykke-Forordningen saa at sige havde vundet Hævd paa, med al sin Haardhed og Tvetydighed, at være baade mild og klar nok, og paa en Tid, da en Trold, Et jeg veed ikke hvad, syndes at have i Bund og Grund ødelagt den Danske LæseVerden", så de førende genrer var døgnblade, prædikener og andagtsbøger, på en sådan tid måtte "sagtens Skribenten af Natur, og af aandelig Nødvendighed, være nær ved at fortvivle om nogen Virkning paa det Nærværende" (123). Under en omhyggelig redegørelse for retssagens faser og for sin manglende lyst til at appellere dommen til Højesteret betegner Grundtvig gang på gang proceduren som udtryk for "Tidens hemmelige Rets-Principer, mod hvilke de aabenbare Love havde ondt ved at seire" (136, jf. 147), og han lader ane, at hans få allierede, A.G. Rudelbach og J.C. Lindberg, holdes ude af videnskabelige stillinger, de er kvalificerede til. En forandring af gældende trykkelov var ønskelig, men at foreslå det kræver forvovenhed, så "at naar man længst har stavet paa Trykke-Forordningen af 1799, for at finde Skrive-Frihedens lovmæssige Grændser, man da nødes til at sige, man fandt ikke engang Trykke-Frihedens, hvad dog kun er lidet, naar det Meste, som trykkes, kan undertrykkes før det bliver læst" (144). Man må faktisk antage, mener Grundtvig, at daværende generalprokurør Christian Colbiørnsen som lovtekstens antagelige pennefører og stilist mest har brugt sit lyse hoved til "at give Advocaterne Leilighed til at øve sig i Dialectiken, eller Skribenterne et Vink om, ligesaa godt først som sidst, at forsage det Nærværende og 
Timelige, trøstende sig, som de kunde bedst, ved det Forbigangne eller det Tilkommende" (145). Loven var "et haardt Ord i rette Tid", dens afskaffelse af anonymitet og forbindelse af ordentlig censur med skrivefrihed var klogt over for staten, men "Forordningens Hoved-Feil blev dens Tvetydighed, og Parallelen mellem Skribent-Feil, en god Borger ogsaa kunde begaae, og qvalificeret Tyveri eller andre andre grove Misgjerninger!" (145). Blot burde juristerne have været lige så liberale som lovgiveren - altså kongen i 1799-tekstens optakt - og ikke have anset tvetydigheden for "en Fuldkommenhed, men for en Feil, hvorunder det var Synd Skribenten burde lide" (145). Vanheldet bestod her $\mathrm{i}$, at det $\mathrm{i}$ den samtidige jura med stadig voksende indflydelse fra "den skarpsindige Tænker A.S. Orsted" (147) blev mode at konstruere en borgerlig ret a priori, som en filosofi mere end jura, ligesom Kant og Fichte havde gjort det med den moralske ret (145). Det kan illustreres med vilkårligheden i P.N. Skougaards og Grundtvigs egen skæbne - førstnævnte blev bl.a. dømt ud fra en henvisning til kirkeritualet, sidstnævnte for at have holdt sig bogstaveligt til det (146, jf. Nielsen 1966, 9).

Grundtvig slutter med at bede kongen om at "restaurere i en sømmelig og forædlet Form det Publicitetens Organ, der er LandsFaderen ligesaa uundværligt som det er Folket" (149). Han skitserer, "hvor let det synes mig, i vore lærerige Dage, at sætte Trykke-Friheden langt snevrere Grændser end den har nu, og det netop til SkriveFrihedens store Gavn, da Staten nødvendig maa sikkre sig for den grændseløse Trykke-Friheds farlige Udsvævelser, før den kan skjænke og betrygge Skribenterne og sig selv en lovmæssig Frihed, der svarer til den, det mundtlige Ord ei nogensteds har, som hvor Frederik den Sjette throner" (149). Grundtvig vil nu nedlægge sin pen for tronens fod og ikke tale eller skrive mere, fordi han er blevet kaldt - skønt ikke dømt som - "Ære-Skjænder", og hans "Ord er, uden Undersøgelse, erklæret for borgerlig dødt og magtesløst, erklæret derfor endog af Cancelliet, som om det var en afgjort Sag, hvad Høieste-Ret vilde dømme". Han konstaterer: "derved er Forbryder-Mærket over min Skrift beseiglet" (151).

Denne tekst var dog for meget af en halstarrig, om end velformuleret og detaljerig forsvarstale for Grundtvigs hidtidige professionelle løbebane som præst og som forfatter til at kunne passere. Grundtvig er vitterligt ikke afklaret, men leverer skarpe udfald imod de vekslende modstandere, surmulende og noget rethaverisk $\mathrm{i}$ tonen, til sidst med en patos, som truer med at gå over gevind.

Også videre under censuren fortsatte Grundtvig sine funderinger over litterær ytringsfrihed. I bogen Politiske Betragtninger med Blik paa Danmark og Holsteen, 1831, skitserer han en litterær republik 
med "en velordnet Skrive-Frihed" til fremme af modne mænds oplysende drøftelser af statens tarv og tidens krav (Wåhlin 1994a, 3645). Han foretrækker i stedet for de så moderne demokratiske rigsdage med mundtlige indlæg og forhandlinger en skriftlig rådgivning. Argumentet er, at skriftligt meddeler man kun noget, man har sat sig godt ind i, mens mundtligt er det "en Æres-Sag, at kunne tale med om Alt" (38). Han foreslår, at skrivefriheden kan ordnes i "det aandelige Reprcesentativ-System, den nødvendig maa være, naar den skal svare til sin Hensigt", ligesom en rigsdag for at kunne fungere må sammensættes af "et mindre Antal" medlemmer, der repræsenterer "det Hele" og ikke accepterer, at folk kommer løbende ind fra gaden og blander sig med dem. Problemet bliver følgelig at få dannet en art litterært rådgivende forsamling, bestående af "et rimeligt Antal PenneFørere, der med Grund kan formodes, i sig at forene hele Folkets Skrive-Dygtighed" (39). Medlemmerne skal mindst være nået til myndigheds alder (dvs. 25 år), ${ }^{10}$ lige så vel som man normalt først kan vælges til rigsdage, når man er omkring de 40 år. Begavelser, der enten er under 25 år eller uden dannelse (som fx Shakespeare i sin tid var det!), kan dog få trykt tekster, hvis en anerkendt og vederhæftig skribent kautionerer for dem. Skrivefrihed skal med rene ord administreres af "den dannede Deel af Folket" (40) og være "et Privilegium for studeerte Moend" (42). Grundtvig udpeger flere fordele herved, $\mathrm{fx}$ at studerende vil interessere sig mere for åndelige idealer og gå mindre op i levebrødsberegninger. Den herskende trykkefrihed trækker desuden ikke "en forsvarlig Grandse-Linie mellem den dannede og den udannede Deel af Folket, hvorpaa dog det Hele beror" (41) og har derfor "næsten givet baade Læse-Nytten og Skrive-Konsten deres Bane-Saar", mens det repræsentative system ved at sortere slette umyndige eller udannede skribenter fra garanterer publikum, at det, der trykkes, er værd at ofre tid på at tilegne sig, og således skaffer "alle Mennesker Læse-Frihed" (42). Til sidst efterlyser Grundtvig i forsigtige vendinger en præcisering af 1799-forordningens alt for uvisse bestemmelser af trykkefrihedens "Omfang og Grandser" eller en helt ny forordning (53). ${ }^{\prime \prime}$

Denne forbløffende elitære model fortryder Grundtvig eftertrykkeligt som "en Vildfarelse" i højskoleskriftet Det Danske FiirKløver eller Danskheden partisk betragtet fra 1836 (GSkv II, 26-27) og indrømmer endog i en offentlig forelæsning i 1838, at han dengang "tænkte som en Bogorm" ( $M M, 489)$. Baggrunden er nok Grundtvigs indtryk fra 1831 af den franske hovedstadspresses uansvarlighed i 1830, der fremkaldte juli-revolutionen, "de parisiske Skole-Drenges Ridder-Spil i Hunde-Dagene" (Wåhlin 1994a, 22-23, jf. 1994b, 79, 1994a, 18). I et politiserende tilbageblik fra 1849 erindrer han, at han 
stadig ville have enhver mundtlig og skriftlig kritik af enevælden som regeringsform forbudt og for de mindreårige og/eller udannede foreslog indført et mildt formynderskab ved de voksne og dannede skribenter (Danskeren II, 67). Men i samme åndedræt tilføjer han, at han dengang overvurderede selv de rimeligste og mildeste enevældige kongers evne og lyst til at tillade drøftelser af "Øvrigheder og Statssager" (68). Grundtvigs ven i Sorø, B.S. Ingemann, ytrede skepsis over for hans formyndermodel og fik straks svar på tiltale (Grundtvig 1882, 109-111, 113-114).

I Det Danske Fiir-Kløver, 1836, bekender Grundtvig, at hverken anonyme eller selvbestaltede forfattere udtrykker folkestemmen. Han foreslår bom sat for "almindelig" trykkefrihed, hvorved umyndige og æreløse skribenter standses, og heroverfor fremme af - lidt vagt defineret - "en Skrive-Frihed med langt videre Grændser og passende Bod for ringe Forseelser" til gavn for "en sømmelig Tone", så “i Regelen" intet trykkes uden godkendelse fra kongeligt udnævnte censorer. Derved gælder sand skrivefrihed "dem, der har baade Forstand i Panden, Aar paa Bagen og Ære i Livet" (GSkv II, 27).

Grundtvig tænker endnu i enevældens muligheder for at udstede privilegier og fastsætte begrænsninger. Dem bekræftede Frederik VI i den bekendte "Vi alene vide"-sag, ${ }^{12}$ da 572 velmenende og egentlig loyale embedsmænd og borgere i København 21. februar 1835 afleverede en trykkefrihedsadresse til kongen (Rubin 1895, 525-527, Jørgensen 1944, 178-180). Grundtvigs indgroede respekt for kongehånden kan være årsagen til, at han ikke var med og heller ikke deltog i stiftelsen af Selskabet for Trykkefrihedens rette Brug 6. marts 1835, der fra 29. maj samme år udgav ugebladet Dansk Folkeblad og også lancerede en række folkeoplysende skrifter. ${ }^{13}$ Grundtvig var dog repræsenteret med optryk af nogle ældre sangtekster i selskabets Samling af foedrelandshistoriske Digte, 1836, redigeret af bibliotekar Frederik Fabricius (SJ I, 310). I midten af 1830'erne var Grundtvig i aktuelle sager mest optaget af indførelsen af sognebåndsløsning. En af trykkefrihedsselskabets stiftere, botanikprofessor J.F. Schouw, appellerede i Dansk Folkeblad, nr. 17, 1837, til, at journalist Johannes Hage fra den nationalliberale avis Fadrelandet blev benådet for den livsvarige censur, som en bøde pådømt ham efter trykkefrihedsforordningen havde medført. ${ }^{14}$ Schouw nævnede i sammenhængen tillige Grundtvig, fordi det hos mange "vækker en ubehagelig Følelse, at en af vore navnkundigste Forfattere, hvis poetiske Genialitet erkjendes af Alle, skal være sat under livsvarig Censur" (Jørgensen 1944, 202). Grundtvig blev aldrig bidragyder til Dansk Folkeblad, men et indlæg i december 1838 imod en anonym artikel i bladet om sognebåndsløsningen viser, at han fulgte med på afstand ( $S J$ IV, 149, SJ II, 132). 
Ville den censurbelagte Grundtvig undgå at provokere den gamle konge, eller var han måske på dette tidspunkt ligefrem enig med ham i, at trykkefrihed skulle have grænser?

\section{Fritagelse for censur}

Som etableret forfatter med en læserskare, der vist nok tidligt var ret stor og trofast (Lundgreen-Nielsen 1980, 858-860), havde Grundtvig følt den personlige censur som en vanærende og uretfærdig slavelænke (BG II, 134-137, 285), for så vidt som der aldrig havde været årsag til at betvivle hans loyalitet over for Frederik VI, enevælden som princip og fædrelandet. Det værste for ham er i 1831 det livsvarige i straffen: han kunne ønske, at "aldrig nogen Skribent, der ei havde syndet til Døden, maatte giøres umyndig paa Livs-Tid, da Haabet i den dannede Verden sædvanlig udretter meer end Frygten" (Wåhlin 1994a, 44). Men i realiteten blev censurtvangen mest en let forsinkende faktor ved Grundtvigs udgivelser (se fx Johansen 1957, 53-54). Han behandledes i reglen velvilligt, gunstigt og humant af de vekslende embedsmænd (jurister fra politiretten) (se fx $B G$ II, 133). ${ }^{15}$ Helt bortcensureret blev kun tredje del af afhandlingen "Om Religions-Frihed" i 1827. Censurperioden kom til at vare godt 11 år og omfatte lidt over 100 trykte tekster, ${ }^{16}$ så selv om denne straf gjorde ham skamfuld og ligefrem fortvivlet, lammede den langtfra hans pen. Grundtvig var nok den danske skribent, som slap bedst fra et møde med den danske enevældes censur.

Ved plakat af 1 . november 1837 mildnedes $\S 20$ fra 1799 til en højst 5-årig censur, når det drejede sig om en borgers første trykkefrihedsdom. Grundtvig søgte hurtigst muligt om fritagelse, som bevilgedes, hvad prins Christian Frederik (siden Christian VIII) lykønskede ham med i et brev af 28. december samme år ( $B G$ II, 286287). En senere oplysning om, at han i glæde skulle have skrevet digtet "Moders Navn er en himmelsk Lyd" julenat 1837, kan ikke verificeres. ${ }^{17}$ Digtet, der offentliggøres i februar 1838 i højskoleskriftet Skolen for Livet, handler slet ikke om censur og ytringsfrihed, heller ikke i den uforkortede originals 20 strofer, som bortset fra ordet "Bog" i strofe 7 udelukkende hylder styrken og inderligheden i det talte og sungne modersmål i kvinders og småpigers munde.

\section{Censur mod mundtlig tale}

Efter fritagelsen fra censur over sine trykte skrifter måtte Grundtvig fra 1839 til 1848 som formand for sin egen nye folkelige foredrags- og diskussionsforening Danske Samfund tage til efterretning, at det 
levende mundtlige ord i denne forsamling regelmæssigt kontrolleredes af Christian VIII's hemmelige agenter. Og det skønt hans dronning, Caroline Amalie, var en af de første rigtige grundtvigianere, endda med et tillidsfuldt personligt forhold til Grundtvig. En række anonyme rapporter i Landsarkivet for Sjælland dokumenterer overvågningen. Ifølge en af disse kongelige spejdere har Grundtvig på mødet den 11 . september 1840 fortalt, at han i London har truffet Norne-Gæst fra Olaf Trygvasons saga og inviteret ham til Danmark, men denne takkede nej af frygt for det danske politi (Lundgreen-Nielsen 1992, 46). Grundtvigs bevarede skriftlige oplæg til denne aften har imidlertid intet herom, så mon ikke han har improviseret humoristisk ved synet af et velkendt spionansigt i forsamlingen? Anekdoten genbruges i BrageSnak, 1844, men nu er Gæst erstattet med Loke (US VIII, 664-667). Hvad der foregik ved Danske Samfunds ugentlige møder, gav dog aldrig anledning til kongelige indgreb eller sanktioner.

\section{Udkast til ny trykkefrihedslov 1844 og Grundtvigs reaktion 1845}

I 1840'erne nærmede Danmark sig demokratisk folkestyre under en moderne grundlov, men Grundtvig var ikke tilhænger af nogen af delene. Debatten om trykkefrihed deltog han derimod livfuldt i. Kongen lod i 1844 et forslag til en ny trykkefrihedsforordning fremsætte for de to kongerigske stænderforsamlinger i Viborg og Roskilde, henholdsvis 18. juli og 16. oktober; her ville han have en del paragraffer fra 1799-forordningen skærpet med strengere straffe (Jørgensen 1944, 272-283). En formodning i Berlingske Tidende 19. februar 1845 om, at stænderforsamlingerne ville skærpe endnu mere, var vist anledning til, at Grundtvig gik i gang med at forfatte en protest (Grundtvig $1845,1)$. I et brev til Ingemann 3. påskedag (dvs. 25. marts) 1845 skriver han: "Saa' du i sin Tid Udkastet til den ny Trykkelov? Traadte det i Kraft, da kunde al Verden række Tungen ad os, og vi maatte dog holde gode Miner, ja, da kunde vi bruge vore Penne til Tandstikkere" (Grundtvig 1882, 281).

Omkring 8. maj 1845 udkom så en 82 sider lang pjece betitlet Udkastet til en ny Trykkelov fra Literaturens Side betragtet og fraraadt af Nik. Fred. Sev. Grundtvig. Denne tekst er langtfra så irrelevant som påstået, fortjener vel ikke et komplet optryk, men heller ikke totalt at være overset. ${ }^{18}$ Det håndskriftlige materiale til den fylder hele 143 sider i kvart (Fasc. 185.I-XXI og 186.IX-X) og består af længere og navnlig kortere passager, som er nogenlunde identisk med trykket, nogle er dog meget bredere, og enkelte er slet ikke trykt. Der er relativt få rettelser; en del små afsnit stryges in scribendo, andre ved læsning 
bagefter, hvorpå alternative linjer indsættes i sidernes marginområder. Særligt interessante utrykte passager vil blive inddraget i det følgende.

Titlen har tre udformninger. Oprindelig hed pjecen: "Udkastet til en ny Trykkelov / paa / Mundens og Pennens Vegne / alvorlig / giennemtænkt og fraraadt" Det rettes til: "Udkastet til en ny Trykkelov / fra / Literaturens Side / frit / betragtet og fraraadt" (Fasc. 185.XIX 57 r). I trykket udelades ordet "frit". Grundtvig har arbejdet materialet omhyggeligt igennem og gang på gang genskrevet teksten, til vidnesbyrd om den vægt, han tillagde sin indgriben.

I et forord sætter Grundtvig emnet ind i en historisk sammenhæng, gående ud fra, at "det er en af de allervanskeligste Opgaver, ved Love at hemme Trykkefrihedens Misbrug uden at lamme Pressens nyttige Brug" (Grundtvig 1845, I). En model over litteraturens verden som "en Falled", hvor både "Afskummet af Befolkningen" og "de Ypperste" har "samme Skrivefrihed", lanceres i et håndskrift (Fasc. 185.XIX 57 r), men overstreges og erstattes $i$ et andet fragment af følgende linjer (Fasc. 185.V $28 \mathrm{v}$ ):

en Fcelled, hvor Afskummet af Befolkningen skal have samme Ret som Kiernen, ${ }^{19}$ hvem der ikke kan holde paa en Pen samme Trykkefrihed, som hvem der har lært at føre den mesterlig; men Eet af To, kan jeg dog umuelig tvivle om, [...] det er langt bedre at dele Friheden end Trældommen med Alle, thi det Første giør dog kun den cedle Virksomhed altid besvarlig og tit frugtesløs, men det Andet giør den umuelig.

Ingen af formuleringerne optages i trykket, måske fordi de er forekommet Grundtvig for ustrategisk elitære.

Videre i forordet skitserer Grundtvig først sin egen historie: han voksede op i 1790'erne til en ung mand 'med levende Deeltagelse for eller imod Alt, hvad der kom til min Kundskab, og med levende Afsky for det Raa og Tøileløse, det Alt nedrivende og Alt opløsende, som dengang ogsaa hos os var Siælen i Døgn-Skriveriet, men ogsaa med den levende Følelse, at det var Udbruddet af en aandelig og hiertelig Sygdom, der umulig kunde helbredes med haandgribelige Midler" (II). Nu i 1845 nærer han stadig "Afsky for Alt, hvad der gotter sig ved at nedrive det Bestaaende, nedsætte det Ophøiede og skamskænde det Herlige" (II). Men som gammel "Historiker" har han erfaret, både på første og anden hånd, "at hin ulyksalige Forstyrrelses og Ødelæggelses-Drift er netop fremkaldt og voxer ved overlegen Undertrykkelse", så den skal kun mødes "med Aands-Overlegenhed, kiærlig Overbærelse og folkelig Oplysning", ikke "med haandgribelige Vaaben, uden naar den selv løfter dem" (III). Altså vil han med "Sindighed og Sømmelighed" og "Frimodighed og Sikkerhed, der egner en gammel Skribent", gå imod Cancelliet (III), selv under risiko 
for en ny retssag: Udkastet er nemlig "heeltigiennem en stor Feiltagelse" (IV).

Grundtvig ser derpå tilbage på trykkefrihedens nyere historie. Den blev i perioden 1770-1800 "aldeles uundvcerlig", og misbrug af den skal dadles, "men dog taales for Brugens Skyld" (V). 1799forordningen indførtes med lammende straffe for ting, der blot eksisterede på tryk som "lidt 'Sort paa Hvidt"”. "Disse Trudsler, et Par afskrcekkende Exempler, og vel især de celdre Skribenters pludselige Taushed, eller vemodige Klager og betænkelige Miner" bevirkede, at unge skribenter enten udeblev på grund af læseverdenens tilstand eller "vendte sig for det meste bort fra det virkelige og narvarende Menneskeliv, især fra Alt hvad der kunde kaldes politisk, republikansk, eller i levende Forstand folkeligt, saa, var der ikke med det ny Aarhundrede opstaaet Digtere, der deels af Naturen er Vovehalse i Ordets Kreds, og deels i Politiken dengang betragtedes som uskyldige Børn", var dansk litteratur selv som navn blevet forældet ved udgangen af perioden 1800-30. "Dags-Litteraturen" fyldtes med pennefejder om navneværdi ${ }^{20}$ og kejserens skæg og blev til sidst tom og øde bortset fra "Læsefrugterne"21 (V-VI) og fra "den indbyrdes Underviisnings 'Laesetabeller" (VI). Under syvårskrigen 1807-14 indskrænkedes trykkefriheden yderligere, og i fredstiden 1814 ff. fortsattes denne tendens (VI-VII). Grundtvig respekterer i 1845 det bestående samfund, men indvender (VII):

Det Allerunderligste er imidlertid dog, at man i vore Dage kan glemme, hvad dog nu er soleklart, at det historisk 'Bestaaende' langtfra at bestaae af eller ved sig selv, kun bestaaer i og ved den Bevaegelse, som vi kalde Menneske-Livet, saa at saasnart denne Bevægelse enten standser eller vender sig fra det Bestaaende, da falder det ved første udvortes Stød, og selv uden Stød kun lidt senere af sig selv!

Han fastslår, at dagslitteraturen ikke har forbedret den tone, som blev resultatet af 1799-forordningens optugtende ånd, end ikke efter 1834 (dvs. stænderforfatningen). Læserne blev derfor ved forhindringer og restriktioner drevet tilbage til litteraturen fra perioden før $1800 \mathrm{og}$ fandt "netop derved de Franske Friheds-Ideer" og gjorde dem "nagelfaste". Hvis en ny trykkelov i 1845 tvinger dem til at foretage den bevægelse én gang til, bliver tilbagegangen fordoblet (VIII).

Tale- og trykkefrihed leder for Grundtvig frem til menneskelivets oplysning, som atter leder frem til redning af folk og riger. Hvor denne frihed findes, kan man tåle byrder og ubehag, men hvor den mangler eller er frarøvet folk, "nedsynker Folket til Faet eller sætter sig paa Bagbenene, som de vilde Dyr, og i begge Tilfælde er det jo forbi med Menneske-Livet!" (IX). 
Grundtvigs politiske mål og ønske er, at de europæiske lande ikke skal have strenge trykkelove, men tværtimod gennem "en grundig Skole-Forbedring" oplyse folket om "Menneske-Livets og det borgerlige Selskabs sande Beskaffenhed, der giør en virkelig Øvrighed ligesaa nødvendig, som den uden virkelige Undersaatter er umulig, og giør det soleklart, at Alles virkelige Deel i Regieringen maatte paa Timen opløse Selskabet og indføre Nave-Retten". Grundtvig henviser positivt til England, hvor pressens tøjlesløshed kun er blevet "cergerlig, slet $i k k e$ frygtelig" (IX), og hvor forbedringer af den derfor kan håbes (X). "Hvor man derimod ikke saaledes i en stor, naturlig og frisindet Stil kan tage sig af Folke-Ungdommens levende Oplysning, fordi man i ingen Retning vil indrømme mere Frihed end man nødes til, der er det vel, i mine Øine, omtrent det Samme, hvad man giør, naar man kun ikke endnu meer indskraenker den Smule Frihed, der i vore forbyggede ${ }^{22}$ Stater endnu er den menneskelige Virksomhed levnet” (X). I Danmark bestræber man sig på at nyordne trykkefriheden, men det netop forelagte udkast viser desværre, at Danske Cancelli ikke evner at skrive en lov herom (X).

Grundtvig mener, at enhver klog regering, der ønsker at give kirke og skole en ny skikkelse, vil spørge kirke og skole til råds og derefter $\mathrm{i}$ Statsrådet undersøge, om disse har søgt at fremme egne interesser på bekostning af helheden (X). På samme måde skal man forholde sig over for litteraturen (dvs. skrift og tryk af fiktive så vel som ikkefiktive tekster): den må, "hvad enten man kalder samme 'den lærde Republik' eller 'Friskolen' eller 'Pressen', i sine egne Anliggender raadspørges først, hvis disse Anliggender ikke, ved en eensidig Betragtning af hvad man kalder det Heles Vel, skal forvirres istedenfor at ordnes" (X).

Grundtvig fortsætter: da litteraturen ikke kun er et nødvendigt onde, men "en folkelig Eres-Sag og et uundværligt OplysningsMiddel", bør den i egenskab af "en lille Magt, der, som enhver foragtet Fiende, hevner sig ved Leilighed (...) høres før den bindes" (XI). Dette skete i 1799 ved den nedsatte kommission og ved mange indlæg i pressen - som fx P.A. Heibergs pjece En Draabe i det store Hav af Skrifter om Skrivefriheden, 1797. Derved blev forordningen drøftet “'til begge Sider,' saa et gientaget Forsøg kunde dog mulig skaffe os en Trykke-Lov, der ikke blot tog Alting i den bedste Mening, men tog ogsaa hele Sagen fra sin bedste Side" (XI).

Grundtvig foreslår helt konkret en prisopgave udskrevet om det nye udkast af 1844. De indkomne besvarelser bedømmes af Højesteret, og den af dem, der bedst belyser forholdet mellem unødvendige indskrænkninger og "bestemte og alvorlige Skranker", videresendes til "Folkeraadet" (stænderforsamlingerne). Efter drøftelse af sagen her 
går den med en vedføjet udtalelse til afgørelse i Cancelliet og i Statsrådet (kongen og hans nærmeste rådgivere). Det ville give Danmark "en Trykkelov, der svarede baade til Majestcetens landsfaderlige Hensigt, Literaturens Tarv, Rettens Skiøn og Folkets Ønsker" (XI).

Derimod præciserer Grundtvig, at af Danske Cancellis skød kan en sådan lov umuligt udspringe, fordi det "paa en dobbelt Maade selv er Part i Sagen, først som Forfatter til de vigtige Skrifter, der ellers udgaae som Lov-Udkast og maa i en fri Literatur tit finde skarp Bedømmelse, og dernæst fordi Cancelliets Bemyndigelse til at sætte Skribenten under Tiltale er en saadan Livssag for hans Virksomhed, at en god Trykkelov maa paa en eller anden Maade sikkre ham for ideligt Thingløberi, ${ }^{23}$ hvad Cancelliet, der naturligviis ikke har isinde at misbruge sin Myndighed, neppe af sig selv vil finde nødvendigt" (XII).

Selve pjecen begynder med en gentagen understregning af Cancelliets inhabilitet. Både det og collegierne har deres "næsten aldeles uindskrænkede Skrive og Trykkefrihed", og kongerne er langt mildere censorer end politimestrene og allermildest lige her (3). Enten må man udarbejde en trykkelov, som gøres til "et hardtad udelukkende Privilegium for Cancelliet", der så foretrækker sig selv, eller også må man til ulempe for Cancelliet lovgive "med særdeles Hensyn paa Literaturens Frihed" (4). Sagen er jo, at enkeltskribenters fejl forbliver deres egen brøde, mens Cancelliets skriftvirksomhed har lovkraft, der kan skade hele det borgerlige samfund og dermed "Almeenvellet", og derfor bør dets skrifter hellere recenseres for skarpt end for lempeligt (4). Polemikken imod Cancelliet og dets embedsmænd anskues herefter fra pjecens gennemgående synsspunkt: spørgsmålet om, "hvad Følgerne blev enten for hver Skribent især eller for Literaturen i det Hele" (5). Ved litteratur forstår Grundtvig hele skriftkulturen, ikke blot digtningen.

1799-forordningen havde $\mathrm{i}$ sin indledning og afslutning en god ånd, men indimellem så mange trusler og indskrænkninger, "som i Danmark aldrig kan være alvorlig meent, og Ubestemtheden af mange saakaldte Bestemmelser er unægtelig Forordningens Skyggeside, som trænger til nøiagtig at oplyses og forsvinde" (5). Det er også en fejl, at Udkastet udelader landsfaderens indledning med anerkendelsen af "Yttrings-Frihedens Uundvorlighed til Folke-Oplysning" og den dertil svarende slutnings "Kongelige Opmuntrings-Ord" (6). Lovgiveren tilkendegav dermed "sin Yndest for Trykkefriheden, sin Erkjendelse af Literaturens store Vigtighed for det borgerlige Selskab, og sin bestemte Villie, at redelige og oplyste Skribenter skal uden Hinder kunne udtrykke sig frimodig om alt Offenligt" (6). 1844-Udkastet 
behandler derimod litteraturen "som en fiendtlig Magt, hvis fri Virksomhed paa alle Maader skulde hemmes eller ved given Leilighed følelig straffes" (8). Efter Grundtvigs vurdering vil det især gå ud over de seriøse danske skribenter, der ikke som de parisiske har "et stort Ry, Tønder Guld og Ministerposter ved Pennen at vinde, men egenlig kun Opoffrelse og Selvfornægtelse fra først til sidst". Resultatet bliver, at folkeoplysning overlades til unge "Fusentaster", der vil gøre opsigt, og "urolige Hoveder", som ser frem til "det Bestaaendes tilstundende Fald" (9). Heroverfor henviser Grundtvig til sin egen bog fra 1831, Politiske Betragtninger med Blik paa Danmark og Holsteen (Wåhlin 1994a), hvor han foreslog politicensuren afskaffet og trykkefriheden reguleret af "personlige Garantier" fra etablerede skribenter på baggrund af disses "Dannelse og Dygtighed" (Grundtvig 1845, 12).

I det følgende gennemgår Grundtvig en række tvivlsomme paragraffer i Udkastet. Et forbud mod at fornærme fremmede magter arbejder med hensigter i stedet for det faktisk skrevne, så sagen ikke afgøres med jura, men kommer til at bero på Cancelliets evne til at skønne rigtigt (16). Den enkelte skribent må imidlertid, med erindring om sværdet over Damokles' hoved ved tyrannens dækkede bord, se i øjnene, at "da hænger hans Skribent-Virksomhed og selv hans personlige Frihed i et Haar", og Grundtvig må her understrege, at cancelliherrerne trods alle "gode Hensigter, Upartiskhed og Skiønsomhed" blot er "Mennesker, ligesom han" (17). Videre forbyder Udkastet, at nogen taler om en forandring af Danmarks statsforfatning - et fast debatemne i 1840'erne - men "som Patriot og Historiker" kan man da godt søge en "følgelig ${ }^{24}$ Udvikling af den" (23), så folket fx indser, "der ingen Modsætning er mellem uindskrcenket Enevoldsmagt paa den ene, og Folke-Raadet, Høiesteret, Nationalbanken og den høieste Grad af borgerlig Frihed paa den anden Side" (24). Om mundtlig ytringsfrihed anfører Grundtvig, at "man maa huske, at der vil endnu langt længere Arme til at lukke alle Munde end til at forsegle alle Penne, og at en Regiering ikke vinder men taber uberegnelig ved, at hvad alle Folk hvisker om, ei maa siges høit" (25). Den store fejl ved juridiske "Lovbud" er, at de med trusler og forbud "netop ramme feil: forfærde, afvæbne og forstemme de gode Borgere, medens de styrke, tjene og paa en Maade retfærdiggjøre de Slette" (26).

Paragraffen imod fornærmelse af hvilken som helst dansk tronarving mener Grundtvig er katastrofal for "Historie-Skrivningen", fordi det i realiteten er et "mageløst Forbud mod al Tids-Historie, som var værd at læse" (26; jf. Møller 1950b, 148). I det hele argumenterer Grundtvig for, at trykkeloven ikke bør behandle skribenter anderledes, end andre love behandler bønder, håndværkere, købmænd og embedsmænd, nemlig ud fra klare økonomisk orienterede regler; skribenter 
bør ikke udsættes for "Søgsmaal og Straf efter dunkle Lovbestemmelser, fortolkede efter Omstcendighederne" (30). Hans program lyder, at det i Danmark er "den store Opgave, ved rolige, stadige Fremskridt at forebygge halsbrækkende Spring, ved Reformation af alle de borgerlige Forhold at undgaae Revolution" (31). Udkastets forbud mod at sætte befolkningsgrupper op imod hinanden, fx under debat af det problematiske misforhold mellem Danmark og hertugdømmet SlesvigHolsten eller mellem herremænd og bønder, er et "Magtsprog", som ikke kan udjævne noget som helst (32).

Specielt for litteraturen skal man i Danmark lovgive som for livet og hverken gennemføre et hebraisk, romersk eller fransk retsbegreb. Princippet bør snarere være at bestræbe sig på (33):

efter den vise Solons Ord, ${ }^{25}$ at give ethvert Folk de Love, der passer bedst for dem, og vil, efter deres Beskaffenhed, virke bedst hos dem; og er det ikke dog en Erfarings-Sandhed, i alle Lande og til alle Tider, at Uenigheden selv mellem de bedste Venner er allerfarligst, naar man slet ikke tør give sin Harme Luft, men skal lade, som Alt er lutter Kicrlighed!

Grundtvig betoner, at den almindelige injurielovgivning ikke egner sig til at blive overført til litteraturen, selv om nu tillægsstraffen af livsvarig politicensur nyligt er blevet fjernet (34, jf. Jørgensen 1944, 190).

Det er ydermere en fejl, at Udkastet arbejder med gradvis tilmåling af straf under hensyntagen til "“den Fornærmedes borgerlige og moralske Veerdighed og til det indbyrdes Forhold mellem ham og Fornærmeren"”, og dette vil være "en heel Revolution i den saakaldte 'larde Republik', hvor hidtil Alle, ligefra Statsministeren ${ }^{26}$ til den løsladte Tugthuusfange, og ligefra Mester-Skribenten til dem der kun skrev med 'paaholden Pen', ${ }^{27}$ havde lige Stemmeret" (Grundtvig 1845, 38). Udfaldet af enkeltsager må så enten bero på et vilkårligt skøn eller på et opslag i (Hof- og) Statskalenderen vedrørende indplacering $\mathrm{i}$ rangklasser (38). Grundtvig beklager "Skribenternes unaturlige PenneFeider paa stemplet ${ }^{28}$ Papir" (40), men kan glimrende forestille sig, at der vil kunne gøres juridisk forskel på cancelliherrerne og den dem meget underordnede præst i Vartov (42).

Til de 11 foreslåede injurieparagraffer bemærker Grundtvig, at det skader dansk litteratur og Danmark, hvis skribenter under drøftelse af lovudkast ved "et Par ubetcenksomme Linier med ildeveiede og stødende Udtryk derom, kunde med Fangsel og Censur afbryde en skiøn Forfatterbane, saa den maaskee aldrig lod sig fortsætte”, og nævner landsforvisningen i sin tid af M.C. Brun og P.A. Heiberg som eksempler (42). Allersørgeligst ville det derfor nu være, "om midt i det Nittende Aarhundrede ligesaa gode eller bedre Hoveder, for langt mindre og tilgiveligere Skrivfeil, skulde stemples til Forbrydere, kastes 
i Fangsel og enten gaae tabte for Literaturen og Fædernelandet, eller fyldes med Harme og Forbittrelse mod det Bestaaende!" (42). Tilmed vil denne lovgivning gå værst ud over ansete og vægtige skribenter, "thi i en lidt urolig Tid er det aldeles umuligt at anlægge Sag for meer end Tiendedelen af de Drillerier og Spydigheder, som høre til Dagens Orden" (43). Loven vil med kravet om at dømme hensigt snarere end fakta gøre prokuratorerne til de "største Lodseiere paa Literaturens Mark" (43). Her henviser Grundtvig til Baggesens versfortælling "Censurens Oprindelse" om Kallundborg-borgmesteren: man kommer med digterens ord til at leve "bandsat" 29 (44, Arlaud 1889, 171).

Heroverfor finder Grundtvig, at "Folkeraadets Oprettelse og dets litercere Offenlighed", altså lovudkasts publicering før deres ikrafttrædelse som gældende lov, er "en Grundforbedring i vor Statsforfatning" (Grundtvig 1845, 45). Folkeråd og litteratur har nemlig for Grundtvigs øjne brug for hinanden til at "aabenbare den virkelige Folkestemme om Lov-Udkastene og Landets Tilstand". Blandt andet fordi kirken, skolen og embedsstanden egentlig ikke er repræsenterede i stænderforsamlingerne, skal litteraturen sættes i stand til at varetage disse parters dyrebareste interesser ved frit at kunne "gaae irette med Raadet om den virkelige Folkestemme" (45). Det minder atter om Grundtvigs 1831-forslag om de dannedes og dygtiges privilegium som rådgivere.

Grundtvig går kraftigt imod Udkastets $\S 42$, hvorefter ord, der i en skribents tabersag er kendt døde og magtesløse, ikke må publiceres, medmindre det handler om "ubeføiede Udeladelser", med det resultat, at "de efter deres Natur alleroffenligste Sager" skulle gøres til "den største juridiske Hemmelighed" (46). Det vil betyde, "at hvad Skribenten kom under Censur, kom i Fangsel og maaskee i Tugthuset for, hvad der berøvede ham maaskee baade hans Nceringsvei, hans Agtelse og hans Udsigter for hele Livet, enten aldrig engang skulde blive offenligt, eller maatte dog, efter Domfældelsen, aldrig nævnes paa Prænt" (47). Det sammenholder Grundtvig med datidens sensationsjournalistik om forbrydelser: "Alle ædle Læsere veed, hvor 'stødende' det er for dem, at see en stor tit unaturlig, forsøgt eller udført Misgierning offenlig beskrevet, stundom undskyldt med partiel Sindsforvirring eller besmykket med mulig ædle Bevæggrunde, men det antages dog at være enten nødvendigt eller dog tilladeligt, for at det kan være vitterligt, hvad man i det borgerlige Selskab tiltales, dømmes og straffes for, og fordi man end ikke bør giøre et Skarn Uret" $^{30}$ (47-48). Ved Udkastets forbud mod offentliggørelse berøves skribenten sin dyrebareste borgerrettighed: "den, ei i Hemmelighed at overvældes af Stats-Magten, dømmes og straffes, berøves sin Næringsvei, sin borgerlige Agtelse og sin personlige Frihed, uden at det giøres vitterligt, hvormed han har forskyldt sin Ulykke og hvad han 
til sit Forsvar eller til sin Undskyldning har havt at sige" (48). Den verbale gentagelse på disse to sider i pjecen er vidnesbyrd om, hvor vigtigt dette punkt er for Grundtvig.

Så vidt har Grundtvig kun registreret og argumenteret imod skærpelser, altså forværringer af retstilstanden. Udkastet bringer svag forbedring i en paragraf om, at kirke, skole og forfattere ikke må stødes, men det opfatter han som "en fattig Trøst", for når man ikke støder nogen,

da er Livet taget af Friheden, hvor stor den saa end kan beskrives, og desuden lever vi paa en Tid, da det Abstractes Tomhed og Afmagt bliver daglig mere indlysende, saa nu kan ingen dygtig Skribent enten drøfte Begreberne om Religion og Moral, om Kundskab og Vidskab, eller om Ret og borgerligt Selskab, uden at lægge Vægt paa Betingelserne for deres velgiørende Indflydelse paa Menneske-Livet og dermed sammenligne deres nærværende Stilling i hans Hiemstavn. Denne praktiske Retning paanøder sig selv Poeterne i vore Dage, saa selv de kan ikke nøies med en Frihed, der indskrænker dem til Tankernes usynlige Verden, men det er dog ogsaa langtfra, at den i visse Maader store Frihed paa Kirke-Marken og i det Hele paa Aandens egne Enemærker, som den Danske Skribent nu alt i to Menneske-Aldere har nydt, enten i Udkastet er bedre hævdet eller klarere udtalt end i Trykkeforordningen af 1799, thi Tilfældet er netop det modsatte (48-49).

Udkastets regler for bogtrykkere og boghandlere kommenteres som "nye eller skærpede Paalæg (...), der vilde endnu meer forknytte vor noksom beklemte Literatur", tilmed således, at straffene skærpes ved "nogensomhelst Overtrædelse af Loven" (56) tidligere. Humoristisk konkluderer Grundtvig, at Udkastet vil gøre den danske forfatters stilling "reent utaalelig", så "det eneste Spørgsmaal maatte vel endnu være, om Skribenten dog ikke kunne hytte sig ved blot at være Overscetter" (57), men en litteratur kun bestående af oversættelser ville hverken regering eller folk være tjent med - og desuden bestemmer Udkastet i § 47, at alle paragraffer også gælder oversættelser! Som en sikkerhedsforanstaltning tilbydes skribenterne i $\S 54$ en politicensur på forhånd - ulogisk nok, bemærker den censurerfarne Grundtvig, den samme procedure, som ellers regnes for en straf (59). I et håndskrift gør Grundtvig mere ud af dette (Fasc. 185.XII 46 r):

Og nu denne, [Censur,] [Politi-Censur, hvor 'forhadt' den], efter Trykkeforordningens egne Ord 'forhadte' Censur, ${ }^{31}$ Politi-Censuren, langt værre end den Universitets-Censur, ved hvis Ophævelse (1770) Majestæten vilde aabne Vei for enhver oplyst og retskaffen Mand til ubehindret at yttre sine Tanker og Meninger om hvad der kunde bidrage til det almindelige Bedste, denne Censur, som en Gunst, som det sidste Redningsmiddel for Skribenten, den vilde jo være et Maal, 
Literaturen kun ved en sørgelig Krebsgang havde naaet; men desuagtet, over i ti Aar har jeg maattet føre Pennen under den, og saalænge varer det sagtens ikke før jeg har afført den, [og] Saa jeg lod mig maaskee dog nok bevæge til at kysse Riset, og tage for en Gunst, hvad jeg længe har gruet for;

men så vil Grundtvig også være straffri for, hvad der nægtes trykning.

Endelig er der videre overvejelser i Udkastet over litteraturen og dens virkemidler, nemlig

den splinterny, og tør jeg troe, mageløse Forskrift: "ved samtlige foranførte Bestemmelser angaaende Trykkefrihedens Misbrug vil der ikke udelukkende være at see paa det Resultat, som Ordene i deres strænge Ordbetydning og grammatikalske Forbindelse føre med sig, men der bør fornemmelig tages Hensyn til den Mening, som nærmest og naturligst frembyder sig for den sunde Menneske-Forstand ved Skriftets Læsning og Opfatning i dets Sammenhæng” (59).

Her har lovgiveren søgt at definere overtrædelser, som det juridiske sprog med sit krav om entydighed og klarhed ikke kan udtrykke, og digteren og litteraten Grundtvig giver forsøget det glatte lag. "Misbrug af Tvetydighed" i sprog og stil kan han godt forestille sig, men hvad der er "nærmest og naturligst" for en sund menneskeforstand, når man skal tage udgangspunkt i ordbetydning og syntaks, "det har jeg ikke været istand til at udgrunde, og kan ei skiønne rettere, end at hermed aabnedes Port og Dør for al mulig Vilkaarlighed" (60-61). "Alt skal afhænge af det uvilkaarlige Indtryk, det Heles Læsning gjør paa Dommeren, med hans os ubekiendte Tankegang, Læselyst, Læsefærdighed, Sands, Forstand, Fordom og øiebliklige Stemning" (61). Ja, det forbydes ligefrem dommeren at holde sig strengt til vidneudsagn om ords betydning og grammatiske kombinationer - han skal dømme "efter den Forestilling af Sagens Beskaffenhed, der, efter Acternes Giennemlæsning, nærmest frembød sig for ham!" (61).

Et håndskrift indeholder en sammenligning med domspraksis $\mathrm{i}$ engelsk retspleje (Fasc. 185.VI 32 r):

Vilde man indvende, at i Engeland dømmes Skribenterne dog ogsaa efter den Mening de Eedsvorne finde normest og naturligst, da er herved tre Ting vel at mærke: først, at det i Engeland kun er meget faa og meget grove Misbrug af Trykkefriheden man straffes for, dernæst at der er tolv Eedsvorne, som maa Alle være enige og endelig, at de har ingen Instrux, som byder dem søge en anden Mening end den der ligefrem udspringer af Ordenes strænge Betydning og grammatikalske Forbindelse

Kladden fortsætter med, at det i Danmark er overladt til en enkeltmand (dvs. fx en politimester) eller til højst en flerhed af 5 (dvs. Hof- og Stadsretten) og 9 dommere (dvs. Højesteret) at dømme efter et vagt 
defineret helhedsindtryk. Afsnittet er ikke trykt, fordi Grundtvig måske har indset, at forskellen på 12, 5 og 9 ikke kunne være så afgørende og svækkede argumentationen.

Grundtvig véd nok, at også 1799-forordningen behandlede ironi og allegori (i sin § 13), men der skulle skribenten frikendes, "naar Meningen findes tvivlsom". Udkastet vil straffe, hvis skribenten har " "tilsidesat pligtskyldig Opmærksomhed eller dog viist Ligegyldighed for de Følger, man ved bedre Overveielse maatte forudseet, Skriftet kunde have for en Medborgers Agtelse"' (61). Grundtvig indvender, at man "ved at bedømme 'ironiske og allegoriske' Former, befinder sig paa Poesiens netop for juridiske Læsere tit vildfremmede Enemarker!", og tilføjer, at dette ville have ramt Niels Klim og Peder Paars (62). Grundtvig vælger to titler fra autoriteten Holbergs forfatterskab, der nu i 1845 regnes for klassikere i dansk litteratur. Skulle en digter, fortsætter han, blive dømt efter en gammel prokurators opfattelse af en spas eller et epigram som skadevoldende for en medborgers agtelse, "da var alle Digtere juridisk forlorne". ${ }^{32} \mathrm{Et}$ håndskrift har her et afsnit om digternes medfødte flertydighed og varme, når de først er kommet på gled (Fasc. 185.VI 32 v-33 r):

dels fordi deres Ord nødvendig ved deres Fylde maa være [udsat] skikkede til at udtydes paa mange Maader, og deels fordi de i Heden slet ikke kan tænke paa, hvad der ligger Iistappene allernærmest, og kan, selv naar det falder dem ind, ikke rette sig derefter uden at tilintetgiøre deres bedste Indfald.

Grundtvig mener, at man godt kan tillade "en tvetydig Digterspas" (33 r) uden at skulle sætte digterne kniven på struben og true med straffe, og han går derfor ind for opretholdelse af den gældende paragraf 13 fra 1799: "Nu skal Digteren dog kun, i saadanne Tilfælde, foreholdes sin Uforsigtighed og formanes til bedre Overlæg for Fremtiden, hvad tit kan falde drøit nok" (Grundtvig 1845, 62, jf. Fasc. 185.VI 33 v). ${ }^{33}$ Efter Udkastets ordlyd ville Jens Baggesen være blevet dømt for sit dristige digt "Oldtids og Nutids Skikke" ved P.A. Heibergs landsforvisning omkring årsskiftet 1799-1800 og også for et senere frækt epigram imod cancellipræsident og justitsminister F.J. Kaas i 1814 (62-63), men efter søforklaringer over for myndighederne slap han $\mathrm{i}$ begge tilfælde med advarsler. ${ }^{34}$ Grundtvig afviser, at virkelige digtere kan skrive "med stadigt Hensyn paa alle Udkastets 61 Paragrapher" og stræbe efter "ængstelig at undgaae hvert Ord, der enten klang lidt satirisk eller kunde dog maaskee tænkes at krænke Sommes 'honette Ambition!' ${ }^{35} \mathrm{Nu}$, haaber jeg, er det soleklart, at naar Udkastet blev Lov, maatte i det mindste Digterne, hvortil ogsaa jeg hører, enten nedlægge Pennen eller omfavne Censuren" (63). Det kunne Grundtvig med sin erfaring som censureret skribent endda finde 
sig i, hvis loven derved fritog for alt andet juridisk ansvar for både det, der tillodes trykt, og det, som undertryktes. Men sådan siger Udkastet ikke - det muliggør tværtimod i sin $\S 61$ en "analogisk" anvendelse, som vil kunne medføre straf for undertrykte tekster (64) - kort sagt: alt, hvad der er strafværdigt på tryk og "i utrykt Skrift og Tale", skal fremover kunne straffes (65).

Om mundtlig tale noterer Grundtvig, at "ved Straffe-Graden skulde der tages billigt Hensyn til 'den ringere Grad af Overloeg, som ordenligviis er forbundet med den utrykte Tale, og den ringere Virkning, samme ligeledes i Almindelighed fører med sig"'. Udkastet kunne her, foreslår Grundtvig, have indføjet en betingelse om offentlighed, men gør det ikke, så alle slags udtryk kan straffes, "om det end kun var sagt inden lukte Dørre eller laae kun opskrevet i vor Pult" (65). Mundtlig talefrihed indgår udførligere $i$ en kasseret oprindelig slutning (Fasc. 185.V $31 \mathrm{v}$ ) :

Reent ud sagt: Danmark har, saalænge vi kan mindes og igrunden altid nydt en høi Grad af Talefrihed, selv hvor Talen var offenligst, og i det hele en Yttringsfrihed i det huslige Liv og den selskabelige Kreds, som selv i den strængeste Censurs Dage har formildet meget og bidraget uberegnelig til at muntre Livet og bevare [Tilfredsheden (...)]

Grundtvigs konklusion er, at Udkastet gennemfører "det blot abstracte og skolastiske Rets-Begreb" ${ }^{36}$ på den litterære verden (66), selv om alle statskloge regeringer bør indrømme frihed til oplysning og derved kulturel blomstring. Fra M.G. Birckner (med bogen $\mathrm{Om}$ Trykkefriheden og dens Love, 1797) husker han et udsagn om, at et uindskrænket monarki bør have uindskrænket trykkefrihed (jf. Fasc. 185.V 29 r, X 43 r, XXI 61 r-61 v, Holm 1888, 157-159), men er enig i, at der bør være nøjagtig ligevægt. Vigtigt er det imidlertid, fortsætter Grundtvig, at man forener en regerings evne til at handle frit med et folks mulighed for at tale frit (Grundtvig 1845, 67). Personligt kunne han ønske, "at Tonen i vor Literatur var baade langt sømmeligere og langt kongeligere end den er, og var jeg blevet hørt 1831, da er jeg temmelig vis paa, den vilde nu været begge Dele, fordi den vilde været langt folkeligere", men det foreliggende udkast er "det forskrækkeligste Misgreb i Danmark, jeg kan tænke mig" (68). Det er følgen af Cancelliets og samtidens "blot boglige, skolastiske Dannelse", men man skal ikke "glemme, at saa let som Folk kan skabe Bøger, saa lidt kan Bøger skabe Folk, eller Menneske-Livet ved nogen Forordning bringes til at bevæge sig mod sine egne Love" (68). Opgaven er nu at kæmpe for "Menneske-Livet" i "den svare Kamp mod Dyre-Livet og Maskin-Virksomheden, som daglig true det med Undergang" - og Grundtvig véd, at han næsten er ene med denne tankegang (68). Hans program er, at man skal "paa alle mulige Maader 
hos hele Folket vække og nære Kiærligheden til personlig Frihed" (69). Det materielle begreb om frihed, ${ }^{37}$ som udbrudte slaver $i$ Frankrig lige før den store revolution stod for, da Bastillen faldt (jf. $M M$, 67-68 og fx 91), er ikke noget ideal, så pjecen slutter med udsagnet (Grundtvig 1845, 70) om, at

Hvor man vil undgaae Slave-Friheden, der er som de vilde Dyrs, der maa man netop i alle Kredse opelske menneskelig og borgerlig Frihed, saa selv Fattigfolk kan føle, selv de har meget at tabe ved enhver Rystelse af det Bestaaende, og trænger høit til en fri og stark Regiering, som den Eneste, der kan beskytte og sikkre alle rolige Borgeres Frihed!

I hele teksten danser Grundtvig således en elegant æggedans mellem "Majestcetens landsfaderlige Hensigt og Udførelsen deraf" (1). Forfatter og redaktør af udkastet var først og fremmest A.S. Ørsted, som dog ikke kom igennem i Cancelliet med alle sine ideer og formuleringer (Jørgensen 1944, 281-283).

Grundtvig giver sit utvivlsomme engagement udtryk i flere tonarter. En garanti for hans vurdering ligger $i$ hans egen lod som en censurdømt, der " $i$ en Menneske-Alder har vovet og opoffret for under ugunstige Omstændigheder at føre Pennen en Dannemand værdig!" (Grundtvig 1845, 18) og "over i ti $\mathrm{Aar}^{38}$ har fundet mig i den Bodsøvelse at skrive Bøger under Politiets specielle Opsyn" (63-64). Og hvis Cancelliet og Højesteret opfatter ordet 'udvikling' som ensbetydende med det forbudte begreb 'forandring', mener han ikke, der er noget at gøre herved, men forsikrer, "det er ikke rimeligt, at nogen dansk Skribent, saalænge Verden staaer, vil have mere Kiærlighed til den danske Statsforfatning, og mere Lyst til at stille den i det fordeelagtigste Lys end jeg, som derfor snart i fyrretyve Aar har hedt servil og absolutistisk" (23) og har "efter min Historiske Drift, altid stræbt at vinde et Overblik af min borgerlige Stilling og røre mig derefter, og er alt en gammel Practicus" (40).

Nutidens presse skøtter Grundtvig ikke meget om. Han taler syrligt om "de senere Aar, da vore Blade har holdt et stort Carneval, og da det, efter gammel Stil, bebuder Lange-Fasten" "39 (36). Frem for blade og aviser foretrækker han bøger, men må acceptere, at "BladLiteraturen" nu engang er "i Tidens Smag" (10), og det må gode love lempe sig efter. Enig med Udkastet er han faktisk i angrebet på "det forargelige Spil med Sjouere, der, naar Bladet idømmes Bøder, afsone dem for ussel Betaling med Fængsel”, uden navns nævnelse en i datiden klar hentydning til Goldschmidts praksis i Corsaren (11, Stender-Petersen 1978, 45, Jørgensen 1944, 258-260, Andreasen 1981, 45-48). 
Netop Goldschmidt bedyrede gerne sin kærlighed til og respekt for Det Danske Cancelli og dets censor, C. Reiersen, i nummer efter nummer i sit vittighedsblad Corsaren, 1840-46, når det var blevet beslaglagt for overtrædelse af gældende trykkefrihedslov. ${ }^{40}$ Samme ironiske humor betjener Grundtvig sig af, når han forsikrer ikke at have glemt, "i hvor fjernt og dog ømt et Forhold jeg staaer til det Høikongelig-Danske Cancelli" (Grundtvig 1845, III-IV). ${ }^{41}$

Grundtvig går også ned i lovudkastets sproglige side. Han indser, at kongen ikke må forventes "at kunne med eet Blik gjennemskue de lange Forordninger, Collegierne nuomstunder udarbeide", hverken i indhold eller stil, hvor i sidste tilfælde "tit en lille Udeladelse, en vis Ordføining og enkelte Udtryk" kan gøre "den bedst meente Forordning høist ubillig og skadelig" (2). I 1799-forordningen gjordes "løgnagtige" beretninger om regeringen strafbare, i Udkastet er tillægsordet rettet til "urigtige" (28), hvad Grundtvig frygter vil gå ud over "hele Statistiken og Dags-Historien" foruden selvfølgelig "Blad-Literaturen" (29).

Grundtvigs utilfredshed registreres i hans billedsprog. Udkastet vil bedømme hensigter i stedet for tekster, men på "Bevceggrundenes' Enemærker, da er vi i dunkle Egne, hvor Troen hersker, og paa Grændsen af Tendens-Processerne" (16). Dets omtale af æreskænderi af embedsmænd er elastisk: "Begrebet udvider sig her i det Grændseløse og Grunden gaaer under En som en Gynge" (37), og heller ikke vedrørende religionsbespottelse har lovgiveren præciseret tilstrækkeligt: "Man seer let, at denne svavende Vidtløftighed, som er Lovsprogets store Lyde, ingenlunde vilde giøre Sagen klarere, men meget mere indhylle den i en Taage, som Skribenten umulig kunde giennemskue" (51).

Grundtvigs pjece skal være modtaget i samtiden med "overordentligt bifald" (SJ II, 273). ${ }^{42}$ Forslaget gav anledning til debat i den oppositionelle nationalliberale presse i København (navnlig Faedrelandet og Kjøbenhavnsposten), hvad der resulterede i to domme (Jørgensen 1944, 284, 242). Behandlingen af det trak i langdrag med udsættelser og overvejelser, og det døde til sidst af sig selv.

\section{Ingen smagsinstans}

Grundtvigs tanke om en halvofficiel litterær domstol blev aldrig til virkelighed, og det var måske godt det samme. Ideen var vel ikke i videre overensstemmelse med hans politiske liberalisme. Da en dansk forfatterforening i $1894 \mathrm{blev}$ etableret, var det mere som en parallel til arbejderbevægelsens fagforeninger end som et dansk akademi (Worsøe-Schmidt, 115-120). Det udløste en en vis larm i den køben- 
havnske opinion, bl.a. foranlediget af en både litteraturpolitisk og personlig kontrovers mellem den højreorienterede efterromantiske forfatter Vilhelm Bergsøe og den brandesianske naturalist Sophus Schandorph. Ifølge et referat i Politiken efterlyste Schandorph ved det stiftende møde 27. november 1894 "med faa Ord (...) en Jury" i foreningens regi (Schumacher 1919, XI), men det fremgår ikke, om den skulle være æstetisk eller kollegialt-juridisk. Senere forsøg på at danne overordnede instanser som Det danske Akademi $1960 \mathrm{ff}$. (hvori indgik 'Det smagende Selskab' fra 1759, egentlig Selskabet til de skiønne og nyttige Videnskabers Forfremmelse) og Den litterære Institution uss 1974 (Worsøe-Schmidt, 241-252) levede heller ikke rigtigt op til Grundtvigs koncept. Måske kan en smagsdomstol, der på én gang anerkendes af staten, af forfatterne og af læserne og offentligheden i det hele, ikke dannes $i$ et demokratisk fungerende samfund med ytringsfrihed. I den henseende hører Grundtvigs skitser hjemme i enevældens dage - på samme vis, som hans kongstanke om én central dansk Folkehøjskole i Sorø gjorde det. Men selv i årene lige op til 1848 kunne han ikke vide, at enevælden ville falde bort så hurtigt og smertefrit, som det skete.

\section{Trykkefrihed under 1849-grundloven}

I sit tidsskrift Danskeren, udgivet fra 22. marts 1848 til udgangen af 1851, offentliggjorde Grundtvig en del bidrag om trykkefrihedslovgivning. Det var til dels taler holdt i Den Grundlovgivende Rigsforsamling, hvor han var medlem fra 8. nov. 1848, og i Folketinget fra og med 30. januar 1850. I en appel, stilet "Til Danmarks Vælgere", fastslår Grundtvig 6. september 1848, at "den grcendseløse Tale- og Skrive-Frihed kan aldrig være saa farlig, at den jo, ${ }^{43}$ som en Eneret for Øvrigheden, der altid har den, er tusind Gange farligere, end naar det er en Frihed, Øvrigheden deler med Undersaatterne" (Danskeren I, 392).

Den 10. februar 1849 indrømmer Grundtvig, at "Ordets Frihed" først gav mening for ham som grundbetingelsen for et sundt og virksomt offentligt liv, efter at han havde oplevet det engelske samfund (i 1829, 1830, 1831 og 1843). Altså er det nu hans mål at kæmpe for "en i borgerlig Henseende saa godt som uindskrænket Frihed for Mund og Pen" (Danskeren II, 68). Derfor ville han forvisse sig om, at 1799-forordningen var død og magtesløs, hvad justitsministeren (C.E. Bardenfleth) til hans forbløffelse ikke kunne bekræfte, men i stedet henviste ham til den mildhed, hvormed dens regler nu praktiseredes. Grundtvig fandt det farligt, at udkastet til en grundlov kun indeholdt en forestilling om frihed under ansvar for 
domstolene uden angivelse af denne friheds grænser, endsige et løfte om senere juridisk præcisering. I et indlæg 9. maj 1849 efterlyste han "en Yttring om Friheden, om Aandens og Ordets Frihed i Riget, en Yttring, som aandede Varme" og ville gøre forsamlingen ære. Han stillede følgende ændringsforslag til grundlovens $\S 72$ (svarende til 1953-tekstens $\S 77)$ : "Der skal i hele Riget være en saa udstrakt Taleog Skrivefrihed, især om alle aandelige og alle offentlige Ting, som det almindelige Vel kan tilstede, og Trykkefrihedssagen skal ordnes ved en dertil svarende Lov", men det blev forkastet med 93 stemmer imod 16 (HGS II, 288-289). Grundtvig blev hjemme fra vedtagelsesmødet for grundloven to uger senere, 25. maj 1849, fordi han ikke fandt den så god, at han kụne stemme for den, men heller ikke så dårlig, at han burde gå imod den (Danskeren II, 334).

\section{Grundtvig og Presseloven af 1851}

Regeringen fremlagde $\mathrm{i}$ foråret 1850 et forslag til en presselov. I folketingstaler 12.-13. april 1850 udmalede Grundtvig de fæle følger, en vedtagelse af det ville få: så godt som al kritik vil blive regnet for strafværdigt smøreri og foranledige "Processer, Mulkter og VaretægtsArrester" (Møller 1950a, 84-85). Talerne trykkes i Danskerens 1850årgang i udvidet og skærpet form. Grundtvig harcelerer bl.a. i fortsættelse af sin argumentation fra 1845 over, at udkastet behandler trykkefrihed som noget farligt og negativt, en fjendtlig magt, der skal overvåges af øvrigheden. Det finder han fremgår rent sprogligt af tekstens brutalt affejende indledningsord: "Intet Skrift maa trykkes her i Riget", efterfulgt af indskrænkende betingelser til sikring af den ro og mag, som er alle cancelliers og justitsministeriers sande lyksalighed (Danskeren III, 161-162). Den negative optakt kunne dog også blot være en rutinemæssig juridisk og altså ubevidst genoptagelse af Christian V's Danske Lov. ${ }^{44}$ Helt jævnt og ujuridisk opholder Grundtvig sig ved "den hadske og haanlige Tone" (Danskeren III, 170), der anvendes om alle dele af den danske bogverden. Selv 1799forordningen bar dog enkelte spor af kærlighed til litteratur og oplysning, mens 1850 -udkastet er skrevet ud fra et forbryderjagtende politisynspunkt: presseloven skal, citeres justitsministeren for, være en "Tvangs-Lov" med indbygget trussel om skærpelse i retning af 1799teksten (242). Med et typisk ordspil mener Grundtvig, at Folketinget er blevet budt "en Presselov, en Klemme-Lov for Trykke-Friheden" i en ægte, men totalt forældet metternichsk visdom (813). Han frygter endog, at han må afbryde sit tidsskrift og personligt "gaae i Landflygtighed" (815). 
Loven om pressefrihed blev vedtaget med 67 stemmer mod 9 (801, 814) og gjaldt fra 3. januar 1851. Grundtvig vil dog ikke give tabt og bebuder en fortsættelse af kampen, fordi han ved tredje- og sidstebehandlingen ikke fik ordet til en afsluttende tale imod lovforslaget. Hvad han ville have sagt, hvis ikke forhandlingen brat var blevet afbrudt, følger så på tryk i Danskeren (ibid., 810-814). Hans Egede Schack havde kaldt ham en gammel ridder, der kæmpede for trykkefrihed som for en gammel dames ære, "hvis Skiønhed, mens de var begge unge, havde indtaget ham", så han som en Don Quijote brød sin lanse for en aldrende Dulcinea. Grundtvig gør opmærksom på, at han aldeles ikke kæmper for den gamle trykkefrihed af 1770 , men for den unge af 1848, den liv- og fortjenstfuldeste frihed, som det "store Omsving" (den fredelige danske marts-revolution) foranledigede, "saa naar Fritalenheden til det yderste forsvarer Trykkefriheden, da er det vist meget naturligt." Grundtvigs skriftlige kommentar i Danskeren til sit ikke-holdte indlæg er, at han skal "blive ved at lee ad dem, der tænker, at denne Presse-Lov bedre kan trodse den Frihed, Nordens Aand kræver som sin Odelsret, end det Papir, hvorpaa Loven trykkes, kan trodse Ilden, der bevæger Vogne og Snekker, saa de kappes i Fart med Ordet og Tanken, hvis Redskaber de herefter ogsaa langt meer end Bogtrykker-Pressen vil være!" (815).

Trods den usvækkede energi, som Grundtvigs udråbstegn signalerer, sluttede hans forsvar for trykkefrihed og angreb på censur her. Steen Johansens altomfattende bibliografi over de tekster, Grundtvig selv lod trykke, har i hvert fald ingen henvisninger til begreberne Censur, Imprimatur og Trykkefrihed i den del af hans forfatterskab, der ligger efter 1851 ( $S J$ IV, 143, 202, 293, jf. Johansen 1957). Enkelte spredte udsagn kan dog opledes. I sine kirkehistoriske vinterforedrag 1861-63, senere publiceret i bogform som Kirke-Speil eller Udsigt over den christne Menigheds Levnetsløb, 1871, taler han noget bagatelliserende om Clausen-sagen i 1826-27 som en ærgerlig injurieproces, "hvorved min Præste-Mund gik i Baglaas, min Pen blev bagbunden" ( $U S \mathrm{X}, 354)$, mens fritagelsen fra censur i 1837 ikke medtages. I det store tankedigt Høinordens Rimkrønike (Fasc. 394.1 og 397.31), selvdateret "Hundedagene 1863", men først trykt i 1930, lader han kong Frederik VI i genrens monologform mindes sit forhold til samtidsdigterne, som "lovpriste Folkestemmen", mens de "Skottede mutte til Penneklemmen / Som alt for haard til en Mund saa blød, / Synet vel kunde jeg halvt kun dele, / Bod blev der raadt dog paa det hele" (PS IX, 600). Det er næsten en alt for fredsommelig konklusion på den afdøde herskers misforhold til trykkefrihed. Grundtvig husker i 1849 tydeligere tilbage på Frederik VI's håndtering af hans sag: hans pen måtte "arbeide i 'Bolt og Jern' hele elleve Aar (1827-38)", og “om 
den egne Overbærelse, jeg ved milde Kongers Naade unægtelig fandt, havde været meget større end den virkelig. var", måtte han "fatte et bittrere Nag til denne ulyksalige Forordning, der i en heel Menneskealder (1800-34) standsede næsten al Rørelse i det offenlige Liv og berøvede det den fremskridende Oplysning, hvortil det høilig trængde, og har siden, lige til 1848, næret en Forbittrelse og en TankeForvirring" grænsende til det landsskadelige (Danskeren II, 66).

At trykkefrihedsspørgsmål gled ud af den gamle Grundtvigs dagsorden, kan have flere årsager. Den forste er muligvis den almindelige og voksende tendens hos ham til i anden halvdel af sit liv at vægte talesprogets levende ord over skriftsprogets døde bogstaver. I den halvdramatiske digtning om en kommende tid, Dansk RavneGalder fra 1860, men først trykt i 1909, foretrækker Grundtvigs norske kvindeskikkelse Guldbrand således den frie tale på den nordiske højskole i Sorø frem for det babelstårn, den moderne bogproduktion danner, navnlig i "Bogmageriets Kanaan" ved Rhinen og Elben, for "tale maa / Enhver for døve Øren, / Der end vil tale som en Bog / Og tale som til Bøger" (US X, 473-474). Sammesteds håner englænderen Klearby tyskeren Denkspruch for at ville gøre det årlige omfang af "Messe-Kataloget" (i Leipzig) til målestok for sit folks åndsliv (US X, 476). ${ }^{45}$

Den anden årsag kan være, at Grundtvig under og efter Treårskrigen 1848-50 bliver mere og mere opmærksom på, i hvor høj grad bøger afspejler tysk væsen, modsat engelsk og nordisk folkeånd, der benytter fri tale. Tyskhed savner i Grundtvigs øjne folkeånd, og hvis det tyske vinder overhånd i Danmark, vil det betyde folkedød for danskerne. Tyskerne er Don Quijoter - Cervantes' helt var som bekendt fordærvet af ridderromanlæsning - og de bekymrer sig alt for lidt for de virkelige livsforhold, mens de stirrer sig blind på deres "Landkort over det grændseløse 'Muelighedernes Rige"" (Danskeren III, 734). ${ }^{46}$ Boggenren kommer til at stå for bogstavtyranni forenet med fantasteri $\mathrm{i}$ forhold til det jævne livs virkelighed. Bøger kan formidle gold lærdom, der er ubrugelig i praksis. Den form for hjemtyskhed vil Grundtvig bekæmpe af al magt, hvor han træffer den i det danske rige (jf. Lundgreen-Nielsen 1992, 112-115).

Endelig havde Grundtvig for det tredje også den meget præcisere og bedre årsag til at lade trykkefrihedsspørgsmålet ligge, at presseloven af 1851 ikke fik de dystre følgevirkninger, han forudså i 1850. Under enevælden kunne administration af trykkefrihed og censur være et spørgsmål om forfatteres liv eller død, både bogstaveligt og borgerligt. Enkeltsager, navnlig angående blasfemi og pornografi, forekommer i retsvæsenet frem til i dag. Men med det totalt ændrede klima for offentlig debat siden indførelse af grundlov og 
parlament i det 19. århundrede og på ny siden ungdomsoprør og kvindekamp i sidste halvdel af det 20 . kommer der faktisk en tendens til, at juridisk domfældelse i det længere løb mere gavner end skader en forfatters litterære prestige (jf. Worsøe-Schmidt 1994, 129-133).

\section{Slutvignet}

Sit syn på censur har den modne Grundtvig flere steder resumeret i det nordisk-mytologiske billedsprog, som han selv elskede, men som hans omgivelser regelmæssigt ikke forstod eller misforstod.

Asernes og vanernes vennelag i den gamle mytologi vidner om, at "de alle, selv Lurendreieren Loke, havde deres Frisprog, saa Ordet var frit som Fuglen i Luften, og selv Asernes Fiender, selv Jetterne kunde frit sige hvad de vilde, med mindre de, som Jetten Vafthrudner, udæskede Odin til en Ord-Strid og satte derved selv deres Hoved paa Spil", hvorimod den vise as taalte "Alle Lokes Naalestik" (Danskeren, III, 247-248). Det sidste udtryk stammer fra Grundtvigs sang "KongeHaand og Folke-Stemme" til stænderdagen 28. maj 1839, strofe 2 ( $V U$ VIII, 151-152), som citeres i helhed i Danskeren.

Loke er i nordiske myter uforudsigelig. Hans baggrund er stærkt blandet. Han er jætte, men fostbroder med Odin og hyppigst bo- og omgangsfælle hos aserne, han er fader til uhyrerne Midgårdsorm, Fenrisulv og dødsdronning Hel og kan skifte køn til gejl hoppe, fødende kvinde eller gammel kælling; han kan også forvandle sig til flue, loppe, laks, sæl, fugl, hest. Ved sine mange intriger skaber han forbindelse mellem guder, der ellers helst passer deres egne områder, er altså en socialt sammenbindende kraft. Overordnet synes han at være dels en kulturfrembringer i lighed med faldne "mestertyve", der som Prometeus, Hefaistos og Lucifer har stjålet ild og lys fra det guddommelige, dels en underholdende drillegud eller en kåd (hof)nar (trickster) med impulsive narrestreger (Vries 1957, 265). Grænseafprøvning er hans specialitet.

Grundtvig gør derfor realistisk nok Loke eller rettere sin opfattelse af ham til markør for menneskelig åndsfrihed. I "Rim-Brev til Nordiske Paarørende", der indleder Nordens Mythologi, 1832, skriver Grundtvig de berømte linjer: "Frihed lad være vort Løsen i Nord, / Frihed for Loke saavelsom for Thor" (US V, 384-385). Ordene er blevet bevingede i dansk dagligtale til illustration af et demokratisk dogme om, at godt og ondt skal have lige vilkår, en fair play-holdning, der naturligvis usagt går ud fra, idealistisk og naivt, at det gode vinder til sidst. Men Grundtvigs oprindelige sammenhæng viser, hvor misforstået en sådan moderne tolerant relativisme er. Grundtvig arbejder ikke med to kategorier, men med tre. Han ser generelt ikke gudeslægterne 
aser og vaner som udelukkende gode, fordi de momentant vakler af formastelig selvfølelse eller lokkes af jordisk seksualitet. Gudernes modstykke er jætterne, den rå materie, ødelæggende af og ved naturkræfter (ild, vand, pest, sult), drevet af rovdyrinstinkter (ulv, bjørn), en forening af åndløshed og hjerteløshed. Det er dem, der censurerer og "fængsler det vingede Ord". Men Lokes drillende vid er netop flyvende ord, altså ånd, og hans tilstedeværelse i Asgård holder guderne vågne og tirrer dem til kamp mod jætterne. Grundtvigs Loke er her hverken Snorres eller Völuspás intrigant, skyldig i Balders død og herefter Ragnarok - snarere typen på en vækker, en igangsætter, nogle gange med vilje, andre ufrivilligt. I et utrykt manuskript fra ca. 1823, "Mythologiens Værd", forstår Grundtvig Odins fostbroderskab med Loke som et syndefald, idet den historiske ånd frivilligt forbinder sig med "den tvetungede Klogskab, for at forevige sig i Verden (Verdens-Klogskab)" (Fasc. 2536 v). Videre sammesteds står: "Loke er Fornuften, tvetydig som den tages i Sproget og findes i Mennesket, Selv-Klogskaben i alle Maader, som, paa sin høieste historiske Punkt, idelig halter mellem Aser og Thurser, mellem Aandens og Kroppens Verden, mellem det Ædle og Nedrige, mellem Kiækhed og Feighed, Ærlighed og Falskhed, men narres og spotter dog i Grunden med Alt undtagen med sig selv" $(8 \mathrm{v})$. Ordet "halter" er i øvrigt et citat af profeten Elias' karakteristik af jødernes vaklen mellem Jehova og Baal (1 Kong 18,21).

Vendingen "undtagen med sig selv" redder Loke over i en tredje kategori. Han har kim til et åndsliv, der endnu ikke har fundet sin ideelle retning. 1832-digtet tillader ham derfor at kappes med Thor og få "Forlov til at bruge sin Mund". Grundtvigs program i rimbrevet bliver slagordet: "Frihed for Alt hvad der stammer fra Aand, / Som ikke ændres men arges ved Baand, / Virker skinbundet det Værste i Løn" (US V, 385). Modsætningen "ændres" - "arges" (dvs. forværres) er en variant af et velkendt ordsprog: "Som man ældes, så arges man". Omtalen af den forgæves og i virkeligheden skadelige binding af ånd afbilder censurens negative virkning. Fortsættelsen lyder med entydig stillingtagen imod jætteverdenen: "Bundet kun være det glubende Dyr, / Som i sit Svælg vil det Ædle begrave”, nemlig Fenris-ulven, der i Ragnarok skal sluge Odin. Når Tyr har mistet en arm på at binde ulven, kan Loke kun "magtesløs" spotte guden, ikke reelt hævne sin søns nederlag. Videre i Nordens Mythologi, 1832, hedder det, at Lokes opfindelse af fiskenettet, da han efter at have udvirket Balders død forfølges af Thor, repræsenterer det dybe træk, at den træske altid selv kommer til at udgrunde "Veien til sin Undergang" og gøre "Mønsteret til Snaren, han skal fanges i" (US V, 700, note **). Men alligevel fejler aserne ved at binde Loke, fordi de dermed binder hænderne på sig 
selv. Loke går igen som "et saadant tvetydigt Væsen hos ethvert Menneske og hos ethvert Folk, der troer paa Meer end de selv begribe, thi hos dem Alle opstaaer der et besynderligt Forhold mellem Anskuelsen og Troen paa den ene Side, og Begrebet paa den Anden" (US V, 702). Det er derfor bedre at lade Loke gå fri under tilsyn af Heimdal (dvs. politiet).

I det 15. foredrag i Brage-Snak, 1844, kaldes Loke en meget tvetydig person ligesom egernet Ratatosk i Ygdrasil-træet - det vævre dyr, der efter Snorres Edda piler op og ned i verdensasken Yggdrasill og formidler onde ord mellem ørnen i toppen og slangen Nidhug, som bider af roden. Men Loke er også en uundværlig figur hos aserne, han er med i alle deres store begivenheder som "Sjalen i Øieblikket eller i den naervarende Tid" (US VIII, 661), og Grundtvig gentager, at da aserne bandt Loke, bandt de deres egne hænder, eftersom han er et eksempel på "den fri Virksomhed" i nuet og dennes "FrisprogsMund". Mennesket handler lige så forgæves som aserne, når det "stræber at helbrede Tidens Foranderlighed og at fængsle Øieblikket til sine forstenede Tanker, Lærebygninger og Indretninger, som Loke til de flade Stene" (US VIII, 666, 663). Grundtvig peger på verdenshistoriske følger af at lænkebinde åndstypen Loke i udviklingen i Frankrig fra Ludvig XVI's tronbestigelse til 1789-revolutionen og Napoleon, hvor Loke og uhyrerne for alvor kom løs, mens han modsat i England og Rusland fik fred til levende virke for Europas frelse fra franskmændene. Grundtvigs nuancerede syn på Loke kommer endelig til udtryk i hans brug af navnet som betegnelse for åndfulde danske forfattere, hvis kristendom Grundtvig ikke er overbevist om er identisk med sin egen. Holberg var i Peder Paars og Niels Klim med til "som Loke" at hente ordets Mjølner-hammer tilbage for at tildele latinskolen dommedagsslag, Henrich Steffens var en Loke, vaklende mellem nordisk og tysk, og Grundtvigs poetiske kollega, Jens Baggesen, kunne ved passende lejlighed fremvise et "Loke-Smil" (US VIII, 632, 577578, 624). Sådanne Loker repræsenterer ånd, ikke ondskab, og er, trods deres begrænsninger, en gevinst for litteraturen.

Disse trykte tekster er klare nok. Loke har tilstrækkeligt med ånd til at kunne forvente tolerance. Det kan dog være et problem, at Grundtvig senere i to renskrevne tanke- og læredigte på en indviklet og diskret måde måske listede sig bort fra, at Lokes lukkede mund og lænkede krop skulle betyde en tilsvarende, men ufrivillig uskadeliggørelses- og lammelsesproces hos dem, der overvinder ham. Med andre ord, at Loke har mindre ret til sit tvetydige væsen og aserne mere til deres fysiske modstand, end Grundtvig har villet indrømme op til og med 1844. 
I den ene digtning, det sære spåkvad Dansk Ravne-Galder, skrevet 1860 og trykt i 1909 (som tilfældigvis nogenlunde er den fremtid, der omhandles!), lader Grundtvig tre kvinder og seks mænd fra lige så mange lande (og kulturer) diskutere menneskelivet, medens de sejler med et dampskib fra København til England (US X, 363-483). Tyskeren Denkspruch citerer Grundtvig for (i Brage-Snak) at have sagt: "At Aser bandt med Lokes Mund / Selv deres egne Hænder." Svenskeren Vettern svarer, at selv den bedste mund kan overile sig, så "den gamle Skjald" - Grundtvig - har "frit bekiendt, / At han ved Lokes Fængsling, / Hvad ellers sjelden ham var hændt, / Tog feil ad Billedsproget, / Saa Aser bandt kun Lokes Mund, / Som vi hans mange Frænders, / Med Strænge af hans eget Ord, / Som kneblede ham Munden". Han fortsætter med, at hvis der er nogen sandhed i, "At Aser paa en Maade / Med Lokes falske Virksomhed / Bandt ogsaa deres egen", skyldes det, at de ved tidens fødsel på skrømt indgik fosterbroderskab med ham ( $U S \mathrm{X}, 434-435)$, altså allierede sig med hans upålidelighed for at drage deres fordel af den. I den anden digtning eller rettere digtkreds, Nordens Myther, skrevet i 1864 og først trykt i 1930, lyder det affejende om mytologiens Loke: "VerdensKlogskab var hans Styrke, / Selvmodsigelse hans Brøst" (PS IX, 185). ${ }^{47}$ Ingen af teksterne blev offentliggjort af Grundtvig selv, og det kan derfor diskuteres, hvilken status de skal tillægges.

Tilbage til udsagn, Grundtvig med sikkerhed står inde for. Snorres groteske myte (i Skáldskaparmál) om Lokes tabte væddemål med dværgsmede-brødrene Sindre og Brok, der vandt hans hoved, men ikke måtte forgribe sig på hans hals og derfor endte med at sy hans mund til, kaldes i Brage-Snak, 1844, en fremstilling af "“Censurens Historie' fra dens tragiske Side", ikke mindre bemærkelsesværdig end Baggesens komiske i "Kallundborgs Krønike". Men Snorre annullerede historien, fordi hans Loke rev syningen af igen, og Grundtvig tilføjer som morale, at man hellere skal lade Loke løbe og bruge mund, "da Mis-Brugen ikke kan forebygges, uden at Brugen med det Samme ophæves, og med Munden Alting, som er værdt at tale om, gaaer reent i Staa", hvad al verdenshistorisk erfaring viser (US VIII, 666, jf. Grundtvig 1845, V).

Som troende kristen hævder Grundtvig absolutte modsætninger liv over for død, lys over for mørke, evighed over for timelighed, frelse over for fortabelse. Som verdslig politiker lærer han at omfatte den nærværende jævne, muntre og virksomme, men aldrig helt rene jordiske virkelighed med kærlighed. "Enhver Tvangs-Lov i det usynlige og uhaandgribelige Ords, altsaa i Aandens fri Verden er følgelig tyrannisk, hvor faa eller hvor mange det saa end er, der spiller Tyran, vil selv have Frihed til at sige alt hvad der falder dem ind, men 
ikke unde hele det borgerlige Selskab og folkelige Vennelag samme Frihed", hedder det i Danskeren i 1850 (III, 250). Nu er mundens, pennens og trykpressens frie brug lige så vigtig for Grundtvig, som regn og solskin er for jorden, og så må man tage et vist mål af giftige urter og ukrudt med i købet (252-253). Fordi menneskehånden ofte er farlig, ja endog kan slå ihjel, kan man dog ikke binde alle hænder uden den største skade for menneskelivet (725-726).

En forfatter af og med god vilje bør, konkluderer Grundtvig i 1850, af staten behandles, ligesom en professionel vægter i byen bliver det $\mathrm{i}$ den lavere sikkerheds og bogstavelige oplysnings tjeneste, når han skaber fred og tryghed ved at patruljere $\mathrm{i}$ gaderne og overvåge deres belysning. Man skal hos vægtere så vel som hos skribenter tage hensyn til "den Frihed", der betinger "Flid og Lyst" i deres gerning ("Dont"), og til "den menneskelige Skrøbelighed og de tit meget indviklede Forhold" (728). ${ }^{48}$ Dette humanistiske udsagn er Grundtvigs varige resultat på området.

\section{Forkortelser}

$B G$ I-II: Georg Christensen og Stener Grundtvig (udg.) (1926), Breve fra og til N.F.S. Grundtvig, bind 1 (1807-20), bind 2 (1821-72), København.

Danskeren I-IV: N.F.S. Grundtvig (1848-51), Danskeren, et Ugeblad, bind 1-4, København.

GSkv I-II: K.E Bugge (udg.) (1968), Grundtvigs skoleverden i tekster og udkast, bind 1-2, København.

Fasc.: Fascikel, dvs. håndskriftskapsel i N.F.S. Grundtvigs Arkiv på Det Kongelige Bibliotek.

$H G S$ I-III: Ernst J. Borup \& Frederik Schrøder (red.) (1930), Haandbog i N.F.S. Grundtvigs Skrifter, bind 1-3, København.

KLE: Kjøbenhavnske lcerde Efterretninger (1809), København.

MM: Svend Grundtvig (udg.) (1877), Mands Minde 1788-1838. Foredrag over det sidste halve Aarhundredes Historie, holdte 1838 af Nik. Fred. Sev. Grundtvig, København.

PS I-IX: Svend Grundtvig et al. (udg.) (1880-1930), N.F.S. Grundtvigs Poetiske Skrifter, bind 1-9, København.

SJ I-IV: Steen Johansen (1948-54), Bibliografi over N.F.S. Grundtvigs Skrifter, bind 1 (indtil 1836), bind 2 (1837-49), bind 3 (1850-72), bind 4 (Rettelser og Tilføjelser. Register), København.

Tidende 1844a: Tidende for Forhandlingerne ved Provindsialstcenderne for Nørre-Jylland (1844), Viborg. 
Tidende 1844b: Tidende for Forhandlingerne ved Provindsialstcenderne for Sjcellands, Fyens og Lollands-Falsters Stifter samt for Farøerne (1844), København og Roskilde.

US I-X: Holger Begtrup (udg.) (1904-09), Nik. Fred. Sev. Grundtvigs Udvalgte Skrifter, bind 1-10, København.

VK 1812: N.F.S. Grundtvig (1812), Kort Begreb af Verdens Krønike $i$ Sammenhoeng.

VU I-X: Georg Christensen og Hal Koch (udg.) (1940-49), N.F.S. Grundtvigs Vaerker i Udvalg, bind 1-10, København.

\section{Litteraturliste}

\section{Værker af N.F.S. Grundtvig}

Begtrup, Holger (udg.) (1904-09), Nik. Fred. Sev. Grundtvigs Udvalgte Skrifter, bind 1-10, København.

Borup, Ernst J. og Frederik Schrøder (1930), Haandbog $i$ N.F.S. Grundtvigs Skrifter. Bind 2: Folkelige Grundtanker, København.

Bugge, K.E. (udg.) (1968), Grundtvigs skoleverden i tekster og udkast, bind 2, København.

Christensen, Georg og Stener Grundtvig (udg.) (1926), Breve fra og til N.F.S. Grundtvig, bind 2. (1821-1872), København.

Christensen, Georg og Hal Koch (1942), N.F.S. Grundtvigs Varker $i$ Udvalg, bind 8, København.

Grundtvig, N.F.S., Fasc. 180.1, 185.III, 185.V, 185.VI, 185.VII, 185.X, 185.XII, 185.XIX, 185.XXI, 253，388.101，388.108, 388.109, 388.112, 394.1, 397.31, 402.c.9.

— (1807), "Om Videnskabelighed og dens Fremme" i US I, 175-202.

— (1809), “Æsthetisk Litteratur. Baggesen” i KLE 1809, 257-268 og 275-285.

— (1812a), “Om Oplysning i Almindelighed og Almueoplysning i Særdeleshed" i Bugge 1958.

— (1812b), "Kort Begreb af Verdens Krønike i Sammenhæng" i US II, $167-422$.

— (1818), "Om Publicum og Publicums Domstol” i US III, 556-572. (1827), “Om Religions-Frihed III" i US V, 97-153.

— (1827), "Skribenten Nik. Fred. Sev. Grundtvigs Literaire Testamente" i $U S \mathrm{~V}, 155-180$.

(1831a), "Politiske Betragtninger med Blik paa Danmark og Holsteen" i Wåhlin, 1994a.

— (1831b), "A. Aschlund om Verdens Bygningen og Misviisningen” i Maanedsskrift for Christendom og Historie, I, København, 278290. 
- (1832), "Nordens Mythologi eller Sindbilled-Sprog historiskpoetisk udviklet og oplyst" i US V, 378-767.

— (1833), "Haandbog i Verdens-Historien. Efter de bedste Kilder. Et Forsøg" i US VI, 7-531 .

- (1844), "Brage-Snak om Græske og Nordiske Myther og Oldsagn for Damer og Herrer" i US VIII, 493-788.

- (1845), Udkastet til en ny Trykkelov fra Literaturens Side betragtet og fraraadt af Nik. Fred. Sev. Grundtvig, København.

- (1848-51), Danskeren, bind 1-4, København.

_ (1860), "Dansk Ravne-Galder" i US X, 363-483.

— (1869), "Tillæg. Det attende og nittende Aarhundrede (17151806)" i US VII, 695-704.

_ (1871), "Kirke-Speil eller Udsigt over den christne Menigheds Levnetsløb" i US X, 80-362.

Grundtvig, Johan (udg.) (1903), "Protokol for Langelands Læseselskab", Den danske Højskole, bind 3, København, 146-186.

Grundtvig, Svend (udg.), (1875), Krønnike-Rim med Indledninger og Oplysninger af Nik.Fred.Sev. Grundtvig. Tredje Udgave, København.

— (1877), Mands Minde 1788-1838. Foredrag over det sidste halve Aarhundredes Historie, holdte 1838 if Nik. Fred. Sev. Grundtvig, København.

- (1882), Grundtvig og Ingemann. Brevvexling 1821-1859, København.

- et al. (udg.) (1880-1930), N.F.S. Grundtvigs Poetiske Skrifter, bind 5 (1883) og bind 9 (v/Georg Christensen, 1930), København.

Johansen, Steen (1948-54), Bibliografi over N.F.S. Grundtvigs Skrifter, bind 1 (indtil 1836), bind 2 (1837-1849), bind 4 (Rettelser og Tilføjelser. Register), København.

— (udg.) (1955), "Om dannelse. Tale af N.F.S. Grundtvig i 'Danske Samfund"” i Grundtvig-Studier 1955, 86-93.

\section{Værker af andre forfattere}

Albeck, Gustav (udg.) (1979), N.F.S. Grundtvigs Dag- og Udtogsbøger, bind 1-2, København.

Andersen, Poul (1940), Grundtvig som Rigsdagsmand og andre Afhandlinger, København.

Andreasen, Uffe (udg.) (1977-81), Corsaren. M.A. Goldschmidts årgange 1840-46 og Efterskrift. Registre, København.

Arentzen, Kr. (1874), Baggesen og Oehlenschläger. Literaturhistorisk Studie, bind 4: 1813-1815, København.

- (1877), Baggesen og Oehlenschläger. Literaturhistorisk Studie, bind 5: 1817-1820, København. 
Arlaud, A. (udg.) (1889), Jens Baggesens Poetiske Skrifter, bind 1: Eventyr og Fortoellinger, København.

— (1899), Jens Baggesens Poetiske Skrifter, bind 4: Blandede Digte. Første Samling 1780-1802, København.

— (1903), Jens Baggesens Poetiske Skrifter, bind 5: Blandede Digte. Anden Samling 1803-1814, København.

Baggesen, August (1844), Jens Baggesens Biographie, bind 2, København.

(udg.) (1846), Jens Baggesens Danske Veerker, 2. Udgave, bind 9, København.

— (1856), Jens Baggesens Biographie, bind 4, København.

Baggesen, Jens (1792), Labyrinten, bind 1, København.

Berg, Asger Ødum (1980), "Om Henry Fielding i Danmark. En komparativ litteraturhistorisk fremstilling" i Danske Studier 1980, København, 5-50.

Bugge, K.E. (1953), "Grundtvigs landemodetaler" i Grundtvig-Studier 1953, København, 81-102.

- (1958), "Grundtvigs tale ved det udvidede landemode i juli 1812" i Grundtvig-Studier 1958, København, 52-68.

Bøje, Grete (1984), "Injuriesagen mod Grundtvig 1825-1826" i Grundtvig-Studier 1984, København, 34-65.

Dahlerup, Verner (1898), "Den to gange hængte tyv" i Dania. Tidsskrift for dansk Sprog og Litteratur samt Folkeminder, bind 5, København, 167-174.

Dam, Poul (1999), "Noget om Myterne omkring den Clausen'ske injuriesag og Grundtvigs censurperiodes afslutning" i GrundtvigStudier 1999, København, 7-26.

Donk, Hella van, Erik Paul Madsen og Teddy Petersen (1989), "Fra fiskalhermeneutik til andre forebyggende forholdsregler (II)" i Teddy Petersen (red.), Skrivefrakhed, Studier i Skandinavistik, bind 3, Tønder.

Glædemark, H.J.H. (1940), "N.F.S. Grundtvigs Nedlæggelse af Præsteembedet i 1826. En kildekritisk og psykologisk Studie" i Kirkehistoriske Samlinger, 6. Rk., bind III, 1940, 201-304.

Holm, Edvard (1888), "Den offentlige Mening og Statsmagten i den dansk-norske Stat i Slutningen af det 18de Aarhundrede (17841799)" i Indbydelsesskrift til Kjøbenhavns Universitets Fest $i$ Anledning af Hans Majestat Kong Christian IX.' Regeringsjubilaeum, den 15. November 1888, København 1888, 1-202.

Høirup, Henning m.fl. (red.) (1966), Guldalderstudier. Festskrift til Gustav Albeck den 5. juni 1966, Aarhus.

Johansen, Steen (udg.) (1955), "Om dannelse. Tale af N.F.S. Grundtvig i 'Danske Samfund' i Grundtvig-Studier 1955, 86-93. 
— (1957), "N.F.S. Grundtvig og censuren" i Fund og forskning i Det kongelige Biblioteks samlinger, bind 4, København, 48-57.

Jørgensen, Harald (1944), Trykkefrihedsspørgsmaalet $i$ Danmark 1799-1848, København (hertil kritik ved Povl Bagge i Historisk Tidsskrift, 11. Række, bind 1, 1944-1946, 183-198).

— (1971), Da censuren blev opgivet, København.

Koch, L. (1889-90), "Bidrag til censurens historie under Fredrik V" i

Historisk Tidsskrift, 6. Række, 2. Bind, København, 67-94.

Kondrup, Johnny (udg.) (1996), Henrik Steffens Indledning til philosophiske Forelcesninger, København.

Lindberg, Niels (1876), Grundtvigs politiske Stade, Odense.

Lundgreen-Nielsen, Flemming (1966), "Grundtvig og Comus" i Høirup 1966, 133-153.

— (1980), Det handlende ord: N.F.S. Grundtvigs digtning, litteraturkritik og poetik 1798-1819, København.

- (1992), "Grundtvig og danskhed", Ole Feldbæk (red.) i Dansk Identitetshistorie, 3, 1992, København, 9-187.

Møller, Erik (1950a), "Grundtvig 1848-50" i Grundtvig-Studier 1950, København, 57-95.

- (1950b), Grundtvig som Samtidshistoriker, København.

Nielsen, E. Brandt (1966): "Peter Nikolaj Skovgaard, Grundtvigs mathematiske ven" i Grundtvig-Studier 1966, København, 7-38.

Oehlenschläger, Adam (1817-18), En Reise fortalt $i$ Breve til mit Hiem, bind 1-2, København.

Rasch, Aage (1968), Staten og kunstnerne. Bevillinger og meninger under enevalde og folkestyre, Århus.

Rubin, Marcus (1895), Frederik VI's Tid. Fra Kielerfreden til Kongens Død. Økonomiske og historiske Studier, København.

Rønning, F. (u.å.) [1913], N.F.S. Grundtvig. Et bidrag til skildring af dansk åndsliv i det 19. århundrede, IV.1, København.

Schumacher, Alexander, "De første otte Aar" i Dansk Forfatterforening 1894-1919, København og Kristiania, 1919.

Steenstrup, Johannes C.H.R. (1889), Historieskrivningen i Danmark $i$ det 19de Aarhundrede (1801-1863), København.

Stender-Petersen, Ole (1978), Kjøbenhavnsposten. Organ for "det extreme Democrati" 1827-1848, Odense.

Tidende for Forhandlingerne ved Provindsialstonderne for NørreJylland (1844a), Viborg.

Tidende for Forhandlingerne ved Provindsialstoenderne for Sjallands, Fyens og Lollands-Falsters Stifter samt for Farøerne (1844b), København og Roskilde.

Vries, Jan de (1957), Altgermanische Religionsgeschichte, 2. udg., bind 2, Berlin. 
Worsøe-Schmidt, Lisbeth (1994), Forfatter i Danmark 1894/1994, København.

Wåhlin, Vagn (1994a), "Politiske Betragtninger med Blik paa Danmark og Holsteen af Nik. Fred. Sev. Grundtvig, Præst" (1831a) i Grundtvig-Studier 1994, København, 18-54, med noterne 54-58.

(1994b), "Grundtvig i politik op til 1830" i Grundtvig-Studier 1994, København, 59-91.

Øst, N.Chr. (red.) (1838), Materialier til et dansk, biographiskliterarisk Lexicon, København, Nr. 148, København.

\section{Noter}

Bidraget er en stærkt udvidet version af en artikel med samme titel offentliggjort i temanummeret Censur af Reception. Tidsskrift for nordisk litteratur, Nr. 62, København, marts 2007, s. 31-38.

$1 \quad$ Kondrup 1996, 191-192.

2 Henvisningen til Østs Materialier nr. 147, 1838, i Nielsen 1966, 13, note 14, skal rettes til nr. 148 (=30. december 1838, sp. 1183-1184), og den der citerede beretning angives ikke at være fra Aalborg Stiftstidende.

3 Når Grundtvig i 1838 omtaler venskabet med Skougaard som betingelsen for sin videnskabelige vækkelse, men "hverken Kraftgrunden eller Livskilden" ( $M M, 272)$, synes formuleringen at afspejle dette Horats-citat.

4 Handlingsgangen $\mathrm{i}$ denne midterepisode svarer $\mathrm{i}$ hovedtræk til en gadevise om en tyv i Dublin, trykt i København midt i 1780'erne (Dahlerup 1898, 167-174, jf. Arlaud 1899, upag., = 399).

5 Desværre er Grundtvigs manuskript ikke bevaret, så det er ikke muligt at se, hvad censor har strøget (jf. Johansen 1957, 56, faksimile af avisspalten med "censurhul", dvs. prikker i stedet for slettet tekst).

6 "Per og Poul" er et fast udtryk for "hvem som helst; helt ordinære mennesker", men er også en hentydning til fornavnene på litteraten Peter Wegner og tylvtemedlemmet Poul Martin Møller. Wegner eller Vegner (pseudonym for A.E. Boye) havde i 1815 optrykt nogle let omarbejdede tidsskriftsindlæg imod Baggesen fra året før sammen med en nydigtet dramatisk Holbergsk scene og et par aktualiserede Wessel-digte i pjecen En liden Morskabsbog for Alle og Enhver eller Bidrag til en Contrafey af den vidtberømte nyeste Critique (Arentzen 1874, 274-278), og Møller havde parodieret Grundtvigs profetstil i "Forsøg til et Himmelbrev i Grundtvigs nye, historiske Smag, fundet af Poul Møller", trykt i Nyeste Skilderie af Kjøbenhavn, No. 101, 19. december 1818 (Vilh. Andersen (udg.), Poul Møller: Skrifter i Udvalg, II, København, 1930, 63-67, jf. Arentzen 1877, 307-310). I første uge af november 1818 havde J.J. Dampe offentliggjort pjecen Skrivelse til Poul Møller fra Peer til fordel for Oehlenschläger (Arentzen 1877, 134-142). Baggesen skrev i Nyeste 
Skilderie af Kjøbenhavn for 25. december 1818 indlægget "Til Peer og Povl. (I Anledning af Grundtvigs opfyldte Spaadom om Tylvtens Pyt.)".

Dette humoristiske udtryk, som allerede står i anden sammenhæng i kapitlet "Madkurven" i Baggesens Labyrinten, I, 1792, bruges af den engelske romanforfatter Henry Fielding om Homers Odyssé ("that eating poem"), jf. Baggesens fodnote i originaltrykket s. 32 (Berg 1980, 31 og 48).

8 I en kladde til Grundtvig 1845 giver Grundtvig i et selvbiografisk tilbageblik følgende årsag: "en af Grundene til at jeg engang nedlagde mit Embede var netop, at en anden Embedsmand ved at omtale et af mine Skrifter ret med Flid kaldte mig en Løgner, [...] [indsat $i$ marginen:] medens alskens Grovheder regnede ned over mig i Bladene" (Fasc. 185.III, $22 \mathrm{r}-22 \mathrm{v}$ ), og at han absolut ville undgå flere injurieprocesser. Hvem denne embedsmand var, er uklart. Blandt de mulige er A.S. Ørsted, J.P. Mynster, Fr. Münter samt en unavngiven religionslærer ved en skole på Christianshavn, som Grundtvig havde opsynspligt over for (Glædemark 1940, 291-292, Bøje 1984, 38-39, Grundtvig 1882, 80).

9 Steen Johansens opgivne sidetal for digtets begyndelse ( $S J$ I, 212) skal rettes fra 467 til 476.

10 Der er ikke tale om en 40 års grænse for skribenter som fejlagtigt refereret i Lundgreen-Nielsen 1992, 26 (hvorefter Wåhlin 1994b, 79).

11 Baggrunden er, som Grundtvig uden at opgive navne antyder, magister J.C. Lindbergs deltagelse i H.N. Clausen-sagen i 1829, som generalfiskal O.E. Høegh-Guldberg ville have pådømt med lovens strenghed for fornærmende udtalelser imod det offentlige, men både Hof- og Stadsretten og Højesteret afsagde frifindelsesdom (Jørgensen 1944, 137, 349).

12 Citatet er ikke korrekt, men dækker godt nok Frederik VI's holdning, nemlig at som landsfaderen altid har virket for folkets og statens vel, "saaledes kan heller Ingen uden Vi være i Stand til at bedømme, hvad der er begges sande Gavn og Bedste" (Rubin 1895, 526).

13 Trykkefriheds-Selskabet er dog nævnt i opremsning to gange i udkast til Grundtvigs pjece fra 1845 imod trykkelovsforslaget af 1844 (Fasc. 185.VII $34 \mathrm{r}, \mathrm{X} 42 \mathrm{v}$ ).

14 I fortvivlelse over at være frataget sin erhvervsevne begik Hage i 1837 selvmord, kun 37 år gammel (Rubin 1895, 534).

15 Også den berømte og berygtede redaktør af det satiriske blad Corsaren, 1840-46, Meïr Goldschmidt, indrømmede på sine gamle dage, at censor C. Reiersen, som han latterliggjorde i nummer efter nummer, var "saa human som man overhovedet kunde forlange af en Kriminalassessor og en Mand af den gamle Skole og i det vanskelige Embede" (Andreasen 1981, 51).

16 En fortegnelse over Grundtvigs censurerede tekster og over tekster, der unddrog sig censuren, er bragt i Johansen 1957, 51-53.

17 Dam 1999, 7-9.

18 Skylden herfor ligger nok i Rønning IV.1, u.å. [1913], 93: "For øvrigt er der ingen grund til at gå nøjere ind på Grundtvigs drøftelse af enkelthederne i udkastet; efter at man nemlig i stænderforsamlingerne havde 
talt lidt frem og tilbage om det, afgik det ved en stille død". Jørgensen 1944 omtaler overhovedet ikke pjecen.

19 Modsætning til "Kiernen" er normalt "Skallen" - betyder ordet her måske det værdifulde resultat af kerningsprocessen? I øvrigt forekommer udtrykket "Afskummet og Udskuddet af Nationen, denne foragtelige Hob, som i Samling med alle andre Nationers Skrab og Krimskrams, udgiør en egen Nation for sig selv" i kapitlet "Herrmansbierg" af Baggesens Labyrinten, I, 1792 (380, jf. Baggesen 1846, 228).

20 Navneværdi er det tekniske udtryk for (økonomisk) pålydende og kan desuden henvise til et digt af Jens Baggesen trykt 21. maj 1814 i hans tidsskrift Lille Søndag-Aften nr. 8, "Smaapennenes honette Ambition" (Arlaud 1903, 244 og 368-369). Baggesen hævder her polemisk, at hans modstandere i København kun kan vinde litterært ry (= forhøjet navneværdi), hvis han gider angribe dem offentligt. Den honnette Ambition er titlen på en komedie af Holberg om en rangsyg borger, trykt $\mathrm{i}$ 1731.

21 Underholdningslitteratur udgivet af århusianeren A.F. Elmquist 1818 ff. i 66 bind med overvejende oversatte tekster, men dog også originaler bl.a. af St. St. Blicher og H.C. Andersen. dvs. så tæt bebygget, at den fri udsigt tabes. dvs. bestandige møder i retsinstanser.

24 dvs. logisk.

25 I Haandbog $i$ Verdens-Historien, I, 1833, var Grundtvig langt mindre positiv over for Solon, hvis lovgivervirke han omtaler hånligt som begyndelsen til den atheniensiske mængdes mageløse "Pøbel-Herskab" (US VI, 281).

Statsministeren er betegnelse for et medlem af Statsrådet, ikke som siden i dansk politisk terminologi regeringens leder.

27 "paaholden Pen" angiver, at indholdet af en tekst er affattet af en anden end den, der navngives som skribent. dvs. i juridiske injuriesager.

29 dvs. elendigt, ynkeligt.

30 Blandt sager af denne karakter kan nævnes Ole Kollerøds mord under et indbrud i 1837 og hans påfølgende dom og henrettelse i 1840 , men Grundtvig kan også have kendt omtale af grove forbrydelser fra tidens skillingsviser.

31 I Motiverne for trykkelovsforslaget anføres ved $\S 54$, at det må erkendes, at beslaglæggelser, som der er ført de heftigste klager over, har bevirket, "at den periodiske Presse derved i en ikke uvæsentlig Henseende er blevet en Censur undergiven, der ved den jevnlige Anvendelse, som Collegiet i den senere Tid har været nødt til at giøre af hiin Myndighed, har faaet et end mere odiøst Udseende" (Tidende 1844a, sp. 556, jf. Tidende 1844b, sp. 248). dvs. fortabt.

33 Colbjørnsen mente 24. december 1793 i anledning af nogle gadeoptøjer i København stadig ikke, at reskriptet af 3. december 1790 skulle skærpes, og ytrede, at "man maatte ikke bryde sig om, at der kunde være Misbrug, 
som Loven ikke rammede, f. Ex. Satirer og Allegorier. Kunde det end hænde, at nogle 'ved List undgik Lovens Straf, da skulde de dog ikke finde Skjul imod enhver god Medborgers Foragt"' (Holm 1888, 146, med note 232).

34 Baggesens lille digt "Oldtids og Nutids Skikke" tryktes i december 1799 i K.L. Rahbeks Charis for 1800 og blev en måned efter antastet af Danske Cancelli (jf. Arlaud 1899, 241, med note om baggrund og sagsforløb 380). "Nutidens Kaas" er et tvetydigt fornærmende udtryk i et andet lille digt, "Raad, som jeg, desværre! ikke har fulgt!", trykt i Baggesens tidsskrift Skuddagen for 13. marts 1814 (Arlaud 1903, 197, med note om baggrund 353-354, jf. Baggesen 1856, 119-125, Jørgensen 1944, 81-82). Kaas er et andet ord for "kurs" (cours, retning), men det var tillige navnet på Frederik VI's justitsminister, som kaldte Baggesen til orden for hans Napoleonsfjendtlighed. De to digte gav dog ikke anledning til formelle retssager og domme ifølge Trykkefrihedsforordningen af 1799, men Baggesen måtte ydmyge sig med sindrigt udformede undskyldninger. En hidtil ukendt af disse er overleveret af Grundtvig, der formentlig har den direkte fra Baggesen, som han fra midten af 1810'erne var personligt bekendt med. Altså: "da Baggesen maatte forklare sig om sit Epigram "Tidens Kaas", tilstod han, at han "ligesaa godt kunde sagt "Tidens Strøm"” (overstreget linje i Fasc. 185.VI 33 r). Det retter Grundtvig til, at han "anførde, at da han vaklede mellem Ordene 'Kaas og Strøm' som lige gode, faldt det ham uheldigviis ind, at han havde en Bekiendter, ved Navn Strøm, som onde Tunger let kunde anvende Verset paa, saa det var kun ved at ville undgaae Skylla, han faldt i Charybdis" (ibid.). En hr. Strøm kendes ikke i Baggesens biografi, så det er nok et eksempel på den type vid, hvormed han ligesom P.A. Heiberg i 1790'erne søgte uden om trykkefrihedsloven. Baggesen har dog ikke bedret sin sag ved at udmanøvrere den humorforladte Kaas, for det var stadig ham, der i høj grad administrativt afgjorde, hvad lov og ret mente om situationen.

Om dette udtryk, se note 20.

Skolastik synes ikke at være behandlet som middelalderligt fænomen i Grundtvigs historieskrivning, så ordet må her være taget i overført betydning. I en anmeldelse af antikopernikaneren Arent Aschlunds bog Om Verdensbygningen, udsendt i juni 1830, i øvrigt med et lille mottodigt af Grundtvig om Tycho Brahe (PS V, 495), omtaler Grundtvig "Forholdet, eller rettere Mis-Forholdet, mellem det Populære og det Skolastiske, (det Folkelige og det Professorlige) i Videnskabeligheden, et MisForhold, der, saavidt jeg veed, er eiendommeligt for Tydskland, men har desværre ogsaa taget Overhaand i vort Norden; og truer, efter min Forstand, med et Barbari. Naar nemlig de Lærde enten ikke kan eller ikke vil skrive livlig og folkelig, men misbruge deres Skole-Kundskaber til at drille og trætte de Ulærde, der selv prøve paa at afsondre KundskabsMaterien fra den skolastiske Form, da maa Følgen nødvendig blive Ringe-Agt hos de Ulærde for Skole-Studierne, og da dog, uden disse, hverken de vundne Resultater kan bevares, luftige Indfald skilles fra betydningsfulde Vink, eller videnskabelige Fremskridt giøres, saa er Mis- 
Forholdet aabenbar en bedrøvelig Ting. Vel gjør jeg ikke Professjon af Lærdom, og indrømmer gierne, at jeg er kun en Lærling i den folkelige Fremstilling, men dog kiender jeg nok til begge Dele, for inderlig at ønske dem forenede, og for at skye saavel Anmasselsen og Løseligheden, der sædvanlig hænger ved den Ene, som Kryheden og Pedanteriet, der saa hyppig ledsager den Anden, saa jeg har grundet meget paa, hvordan det sørgelige Mis-Forhold kunde hæves" (Grundtvig 1831b, 285-286). Løsningen kan være oprettelsen af "en Høi-Skole for populær (folkelig) Videnskabelighed, der holdt Universitetet i Skak, og holdtes ligedan af det", og en fodnote foreslår en sådan henlagt til "det Ridderlige Academi i Sorø" (286). Tak til K.E. Bugge for henvisningen til dette sted.

37 Grundtvig kalder det en "Dødens Frihed" i 1869 i tillægget til sit trebindsværk Haandbog $i$ Verdens-Historien 1833-43 (US VII, 698). Den tøjlesløse og blodbesudlede frihed i årene 1789-93 i Frankrig har Grundtvig allerede skildret som et afskrækkende eksempel i VK 1812 (US II, 339-340).

38 Både trykket og et håndskrift (Fasc. 185.XII 46 r) har denne ordfølge.

39 Karneval er den løsslupne fest før langefasten, der strækker sig over 40 søgnedage fra askeonsdag til påskesøndag. Grundtvig mener åbenbart, at pressens uansvarlige og spottende optræden over for enevælden og myndighederne er forspillet til en lang stille og mat periode på åndelig sultekost - dog måske med håb om en påskeopstandelse til sidst.

40 Gode eksempler på Goldschmidts kattevenlighed findes især i årgang 1842 (nr. 74 er det bedste, jf. også nr. 64, 67, Ekstra-No [ml. 65 og 66], 69, 70, 75; tegning af Reiersen i nr. 63).

41 Corsaren karikerede i øvrigt også lejlighedsvis Grundtvig, dog mest relativt godmodigt (Lundgreen-Nielsen 1992, 53), mens han på sin side vist ikke interesserede sig for bladet, hvis talrige småangreb på den danske enevælde og endog på kongens person han ud fra sit historiesyn måtte misbillige. I en tale i Danske Samfund om dannelse, holdt 4. maj 1841, nævner Grundtvig dog lige de hyppige redaktørskifter, der var Corsarens taktik over for censuren (Johansen 1955, 86-87, med note 3 ).

Også Corsaren var opskræmt over lovudkastet. Allerede nr. 192 af 17. maj 1844 indeholder en tegning af fire mænd fra Cancelliet, der smeder en stor hængelås; teksten ironiserer over, at Cancelliet i løbet af mere end 5 år ikke har kunnet bygge hovedstaden et nyt arrest- og tinghus, mens det på kun 1 måned vil udarbejde en ny presselov, antagelig fordi lysten her driver værket. Nr. 199 af 5. juli 1844 bringer en opdigtet reportage af, hvorledes den gamle presselov af 27. september 1799 følges til graven af sine nærmeste, nemlig censurbelagte skribenter, politi og censorer. Et "Forslag til en ny Trykkefrihedslov" fremsat af en (fiktiv) komité af københavnske borgere i nr. 233 af 7. marts 1845 er måske ligesom Grundtvigs lidt yngre pjece foranlediget af aktuel avisdebat. Her foreslås pressefrihed for to typer skribenter, for det første de virkeligt seriøse, der er som læger for staten og bør autoriseres af kongen selv, for det andet de grove, men undertiden nødvendige, der er statens barberer, som rigtigt kan barbere og gennemhegle efter behov, og borgerskab til dem kan som 
til andre håndværkere autoriseres af magistraten. Alle tre bidrag er anonyme, men nok skrevet af Goldschmidt. Om så er, kan altså også en overbevist republikaner tænke i enevældens privilegiepraksis "jo" efter en nægtende sætning betyder på ældre dansk "ikke".

5 af 6 stykker om trykkefrihed i Danske Lov, 1683, begynder med det nægtende ord "Ingen" (2-21-1-3 og 5-6).

Grundtvigs skepsis over for bøger fremgår tidligere ud over af $V K 1812$, VK 1817 og skoleskrifterne af to digte i Krønike-Riim, "Syvaars-Krigens Tid" (tilsat i 1842-udgaven) og "Frankerig" (både i 1829- og 1842udgaven), hvor oplysningstidens berlinske bogproduktion og franske encyklopædi hænges ud for ugudelighed (Grundtvig 1875, 173, 181-182). Før Treårskrigen 1848-50 var det endnu en almindelig folkelig forestilling i Danmark, at den typiske tysker var en tyk øldrikkende og naiv dumrian, der levede $i$ et teoretisk rige stykket sammen af latterlige småstater. Han var stolt af national storhed i en fjern fortid, men i realiteten var Tyskland den evige slagmark for udenlandske magters krige. Vittighedsbladet Corsaren leverer i både tegninger og tekst navnlig i årgangene 1845-46 karikaturer af tyskere som vandrende ølkrus, vandrende rytterstøvler eller vandrende sabler, alle med martialske knebelsbarter (se fx nr. 259 af 5. september 1845, nr. 317-318 af 16. og 23. oktober 1846, nr. 320 af 6. november 1846). Særdeles komisk er den prøjsiske orlogsflåde (én robåd med én admiral og én menig rorkarl, nr. 325 af 11. december 1846). I nr. 310 af 28. august 1846 klages på skrømt over den bekymrende larm fra Tyskland, hvor advokater, professorer og studenter råber op om forsvar for tysk nationalitet, også fra Sachsen, "hvor Borgerne ifjor bleve nedskudte med Geværskud, og fra Preussen, hvor Borgerne iaar bleve stukne med Bajonetter". Konklusionen er dog beroligende: "Vi Danske have blot den Trøst, at det gaaer disse Vogtere som andre vellænkede Porthunde: de giøe forskrækkelig og springe saa heftig frem, som om de vilde sønderrive Lænken; men, løser man den, saa krybe de ganske slukørede ind i Hundehuset." Med Bismarcks magtovertagelse og den deraf følgende politiske og militære aktivitet og effektivitet først på Prøjsens, siden på det andet kejserriges vegne måtte danskerne revidere deres opfattelse af det store nabofolk.

I Krønike-Riim til Børne-Lardom, 1829 (2. udgave 1842), forbindes udtrykket "Verdens-Klogskab" i det negativt-ironiske digt "RomerMagten" med det hedenske og det katolske romerrige, begge ledet af røverbander med disses egennytte til formål (Grundtvig 1875, 58-66).

Meget apropos debatten anno 2007 om det offentliges detaljerede kontrol med rapportering fra og evaluering af sine ansatte advarer Grundtvig i $1850 \mathrm{om}$, at hvis en vægter skulle spørge sin overordnede (politiassistenten) om tilladelse til at handle i hvert konkret tilfælde eller skulle melde alle den forgangne nats begivenheder næste morgen og være $\mathrm{i}$ stand til at navngive alle skyldige for optøjer og tyverier i sit område, ville det snart blive vanskeligt at skaffe "fribaarne, dygtige og virksomme" folk til vægterstillinger (Danskeren III, 728-729). 